University of Nebraska - Lincoln

DigitalCommons@University of Nebraska - Lincoln

USDA National Wildlife Research Center - Staff Publications
U.S. Department of Agriculture: Animal and Plant Health Inspection Service

2014

\title{
Biology and Impacts of Pacific Island Invasive Species. 11. Rattus rattus, the Black Rat (Rodentia: Muridae)
}

Aaron B. Shiels

USDA, aaron.b.shiels@aphis.usda.gov

William C. Pitt

Robert T. Sugihara

Gary W. Witmer

USDA-APHIS-Wildlife Services, gary.w.witmer@usda.gov

Follow this and additional works at: https://digitalcommons.unl.edu/icwdm_usdanwrc

Part of the Life Sciences Commons

Shiels, Aaron B.; Pitt, William C.; Sugihara, Robert T.; and Witmer, Gary W., "Biology and Impacts of Pacific Island Invasive Species. 11. Rattus rattus, the Black Rat (Rodentia: Muridae)" (2014). USDA National Wildlife Research Center - Staff Publications. 1404.

https://digitalcommons.unl.edu/icwdm_usdanwrc/1404

This Article is brought to you for free and open access by the U.S. Department of Agriculture: Animal and Plant Health Inspection Service at DigitalCommons@University of Nebraska - Lincoln. It has been accepted for inclusion in USDA National Wildlife Research Center - Staff Publications by an authorized administrator of DigitalCommons@University of Nebraska - Lincoln. 


\title{
Biology and Impacts of Pacific Island Invasive Species. 11. Rattus rattus, the Black Rat (Rodentia: Muridae) ${ }^{1}$
}

\author{
Aaron B. Shiels, ${ }^{2,4}$ William C. Pitt, ${ }^{2}$ Robert T. Sugibara, ${ }^{2}$ and Gary W. Witmer ${ }^{3}$
}

\begin{abstract}
The black rat, roof rat, or ship rat (Rattus rattus L.) is among the most widespread invasive vertebrates on islands and continents, and it is nearly ubiquitous on Pacific islands from the equatorial tropics to approximately 55 degrees latitude north and south. It survives well in human-dominated environments, natural areas, and islands where humans are not present. Rattus rattus is typically the most common invasive rodent in insular forests. Few vertebrates are more problematic to island biota and human livelihoods than $R$. rattus; it is well known to damage crops and stored foods, kill native species, and serve as a vector for human diseases. Rattus rattus is an omnivore, yet fruit and seed generally dominate its diet, and prey items from the ground to the canopy are commonly at risk and exploited as a result of the prominent arboreal activity of $R$. rattus. Here we review the biology of this invasive species and its impacts on humans and the insular plants and animals in the Pacific. We also describe some of the past management practices used to control $R$. rattus populations on islands they have invaded.
\end{abstract}

FEW Undomesticated animals are as widespread and well known as the black rat, Rattus rattus L. (Figure 1). This rat's behavior results in countless negative interactions with humans in most parts of the world, including consuming and spoiling foods, causing fires and electrical interruptions by gnawing wiring in buildings, nesting in and around human dwellings, and carrying diseases such as the bubonic plague that has killed millions of people (Wilson 1968, Twigg 1978, Alderton 1996). Human impacts and associated costs in attempts to control or eradicate this species have continued for centuries. The success of $R$. rattus in such a range of different environ-

\footnotetext{
${ }^{1}$ Manuscript accepted 17 July 2013.

${ }^{2}$ U.S. Department of Agriculture (USDA), Animal and Plant Health Inspection Service (APHIS), National Wildlife Research Center, Hawai'i Field Station, P.O. Box 10880, Hilo, Hawai'i 96721.

${ }^{3}$ USDA, APHIS, National Wildlife Research Center, 4101 Laporte Avenue, Fort Collins, Colorado 80521.

${ }^{4}$ Corresponding author (e-mail: ashiels@hawaii.edu).
}

Pacific Science (2014), vol. 68, no. 2:145-184

doi:10.2984/68.2.1

(C) 2014 by University of Hawai'i Press

All rights reserved ments across the planet is intriguing, especially when considering that rodents compose over $40 \%$ of the world's mammal species (Alderton 1996); thus there must be some characteristics facilitating the success of $R$. rattus that further separate this species from the other 2,000 or more rodent species on the planet. Perhaps the most important characteristic for success is that $R$. rattus is highly commensal. The ability of black rats to live closely and successfully with humans has facilitated their transport to, and establishment on, most islands in the Pacific, as well as into most of the world's biomes (Alderton 1996).

In addition to affecting human health and economies, $R$. rattus is well known for its negative effects on a large suite of native biota and ecosystems. Rattus rattus has been identified as the most damaging invasive rodent to island ecosystems (Ruffino et al. 2009, Traveset et al. 2009, Banks and Hughes 2012); and globally, $R$. rattus is associated with the greatest number of declines or extinctions of native island biota (Towns et al. 2006). Because most of the islands in the Pacific lacked native land mammals, native flora and fauna are particularly at risk to the negative effects of introduced rodents such as $R$. rattus. Unlike most other introduced mammals on Pacific 

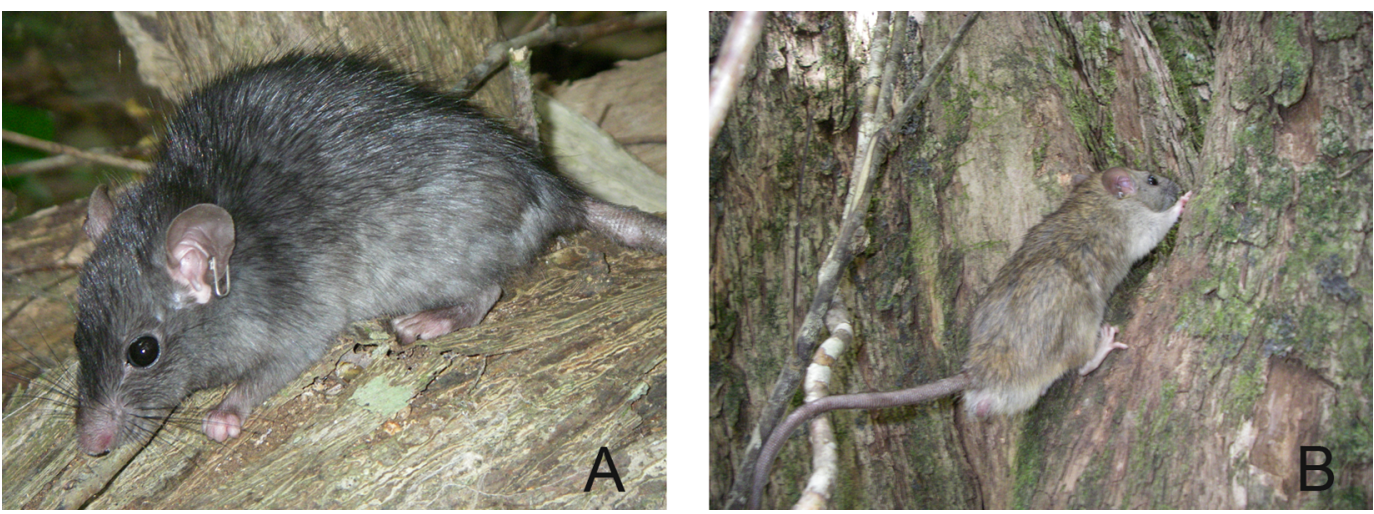

FIgURE 1. Adult black rats (Rattus rattus) with $(A)$ a black pelt and $(B)$ a brown pelt, shown climbing a tree in native forest, O'ahu, Hawai'i. Note the shiny metal ear tags in both photos. (Photographs by A. B. Shiels.)

islands (e.g., ungulates, dogs, cats, mongooses, or stoats), $R$. rattus was unintentionally introduced to islands.

\section{NAME}

Rattus rattus Linnaeus, 1758 (Rodentia: Muridae), is commonly called the black rat, roof rat, or ship rat. Past synonyms have included Mus rattus Linnaeus, 1758; Mus alexandrines Geoffroy, 1803; Musculus frugivorus Rafinesque, 1814; Mus novaezelandiae Buller, 1870; plus numerous others (Innes 2005a). In evolutionary terms, the genus Rattus originated about 2-3 million years ago (Aplin et al. 2003).

Rattus rattus has been separated into two subgroups based on chromosome numbers (Yoshida et al. 1974). The Oceania group of $R$. rattus generally has $2 n=38$ chromosomes (Musser and Carleton 2005), and it was this species that was thought to have originated in the Indian Peninsula and reached Britain by the 3 rd century A.D. (Innes 2005a). The second group of $R$. rattus is an Asian form that has $2 n=42$ chromosomes and is indigenous to Southeast Asia; today it is also found in Japan, Taiwan, the Philippines, New Guinea, Fiji, and other islands (Robins et al. 2007). This Asian group is potentially multiple species and called $R$. tanezumi (syn. $R$. diardii) by Musser and Carleton (2005). Phylogenetic restructuring of the " $R$. rattus complex" (Oceanic and Asian groups) continues to progress, and based on molecular evidence there are almost certainly multiple species within what has historically been identified as Rattus rattus (e.g., five to seven species in the $R$. rattus complex described by Robins et al. [2007] and Pagès et al. [2010], respectively). In the Mariana Islands, Wiewel et al. (2009) reported that all species in their sampling that had been previously believed to be $R$. rattus or $R$. tane$z u m i$ were most closely related to the $R$. diardii group described by Robins et al. (2007). Without molecular analysis of individuals within the $R$. rattus complex, it is very difficult to separate the species, and $R$. rattus and $R$. tanezumi are almost impossible to distinguish morphologically (Aplin et al. 2003). In addition, three interbreeding color morphs of $R$. rattus have been described in the Pacific (Tomich 1986, Innes 2005a): $R$. r. rattus (black individuals), $R . r$. frugivorous (whitebellied), and $R . r$. alexandrinus (gray-bellied). For simplicity, we have not distinguished among species or color morphs within the $R$. rattus complex and therefore consider all of those species within the complex as the black rat, $R$. rattus.

DESCRIPTION AND ACCOUNT OF VARIATION

\section{Species Description}

The black rat, $R$. rattus, is an arboreal, groundactive, and fossorial rodent that is not always black in pelage (Figure 1). A recent review of 


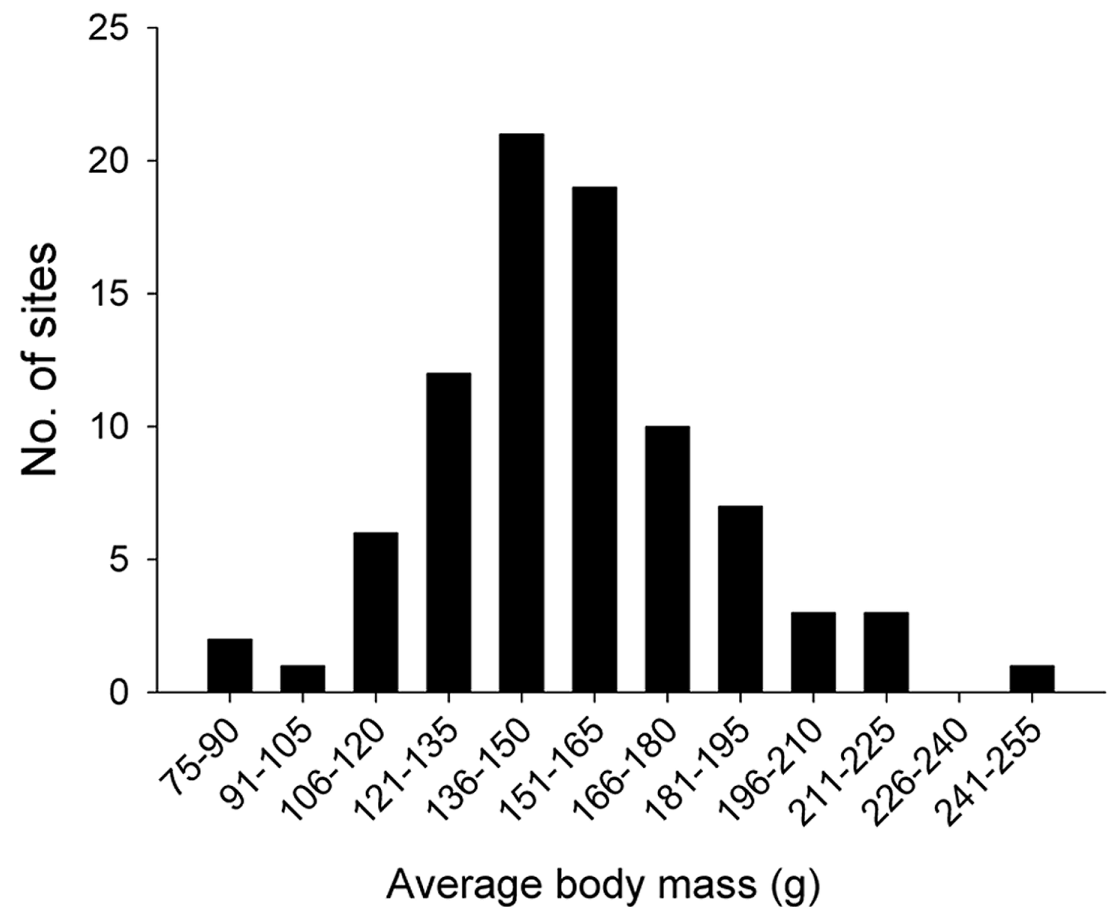

Figure 2. Frequency of average adult body mass of Rattus rattus on Pacific island sites ( $n=85$ sites, representing 59 islands; latitudinal range of islands was $0-55$ degrees).

$R$. rattus body sizes from islands extending across the Pacific basin reveals that mean $( \pm \mathrm{SE}$ ) adult body mass is $153 \pm 3 \mathrm{~g}$ (range, $76-243 \mathrm{~g} ; n=85$ sites, 59 islands) (Figure 2) (A.B.S., J. Russell, and W.C.P., unpubl. data), whereas the mean adult head-body length (measured from snout to base of tail) is $175 \pm 2$ mm (range, $134-207 \mathrm{~mm} ; n=71$ sites, 53 islands) (A.B.S., J. Russell, and W.C.P., unpubl. data). These Pacific-wide $R$. rattus body size measurements were similar to those summarized across New Zealand (Innes 2005a). Unlike other invasive Rattus species (YomTov et al. 1999, Atkinson and Towns 2005), there does not appear to be a Pacific-wide pattern of greater body size with increasing latitude for $R$. rattus (Yom-Tov et al. 1999; A.B.S., J. Russell, and W.C.P., unpubl. data). Adult male $R$. rattus are larger in both mass and body length than adult females (Innes 2005a, Shiels 2010), whereas average tail length has been recorded as similar between sexes (Innes 2005a) or slightly greater in males than in females (Shiels 2010).

Black rats, like most nocturnal rodents, have well-developed senses of touch, smell, and hearing. Both their whiskers and guard hairs (on their pelt) are very sensitive to touch, and they are used in orientation and movement in the dark. Their keen sense of smell allows them to find food and water, detect sexually active individuals, and distinguish foreign and familiar individuals and locations (Mallick 1992, Innes 2005a,b). They have round, dark eyes that are specialized for nocturnal vision; their eyes are very sensitive to light, but their vision is not acute (Innes 2005a).

The fur of black rats is smooth, and the guard hairs on their back are longer than any other hair on their body. As a result of their frequent grooming, they incidentally swallow some of their hair and it may compose an average of $5 \%$ by volume of their stomach 
contents (Shiels et al. 2013). All four feet are dorsally hairy and ventrally bare, and each foot has clawed toes that are essential for climbing: the forefeet have four clawed toes and the hind feet have five. Unlike $R$. exulans (Pacific or Polynesian rat), the dorsal hair on the hind feet is uniformly colored in $R$. rattus, and the hind feet measure $3-7 \mathrm{~mm}$ longer on $R$. rattus $(28-30 \mathrm{~mm})$ than on $R$. exulans (Atkinson and Towns 2005). Female $R$. rattus generally have 10 nipples (range, 10-12), consisting of two pectoral pairs and three inguinal pairs (Atkinson and Towns 2005).

Like $R$. exulans and $R$. norvegicus (Norway rat), $R$. rattus has 16 teeth, which are comprised of four incisors (two on the top and two on the bottom) and six molars on each side of the mouth (Innes 2005a). All teeth grow continuously throughout life, and the large incisors, which are specialized for gnawing and grinding, must be kept to a usable length by grinding and self-sharpening (Innes 2005a). The skull is also specialized for gnawing, and the average length of $R$. rattus skulls in the Pacific region is $40-43 \mathrm{~mm}$ (Yom-Tov et al. 1999). Because of the size variability across ages, the size of $R$. rattus droppings (6.8-13.8 $\mathrm{mm}$ ) cannot always be used to distinguish the species from other species of common invasive rats (Atkinson and Towns 2005).

\section{Distinguishing Features}

Body mass is a characteristic that can occasionally be used to distinguish $R$. rattus from other invasive rodents, but it is often unreliable given that rat body size varies depending on location of capture and level of maturity (Miller and Miller 1995, Shiels 2010) (Figure 2). For example, when adult body masses were reviewed in New Zealand, $R$. rattus individuals were 52-295 g (Innes 2005a), which overlaps with the smaller $R$. exulans (30-187 g) (Atkinson and Towns 2005) and the larger $R$. norvegicus (103-422 g) (Innes 2005b). Instead of body size, features that distinguish $R$. rattus from other coexisting rodents (e.g., $R$. exulans, $R$. norvegicus, and Mus musculus [house mouse]) include tail length and ear length. The tail of $R$. rattus is approximately $27 \pm 2 \mathrm{~mm}$ (or $16 \% \pm 1 \%$ ) longer than the rest of its body
(Innes 2005a, Shiels 2010), whereas $R$. exulans, $R$. norvegicus, and $M$. musculus all have tails approximately equal to or shorter than their body length exclusive of the tail (Atkinson and Towns 2005). The longer tail and sleek body shape of $R$. rattus may be adaptations related to their arboreal activity (Figure 1 ), which is more frequent than that of other introduced Rattus spp. and mice (Shiels 2010, Foster et al. 2011, King et al. 2011a). Ear length of $R$. rattus $(19.0-26.0 \mathrm{~mm})$ is generally the largest among the four main invasive rodents introduced to Pacific islands, including $R$. exulans $(15.5-20.5 \mathrm{~mm}), R$. norvegicus (14.0-22.0 mm), and M. musculus (12.0-15.0 $\mathrm{mm})$. The ears of $R$. exulans, like those of $R$. rattus, cover the eyes when pulled forward, and the fine ear hairs do not extend beyond the edges of the ears, which is unlike those of $R$. norvegicus and $M$. musculus (Atkinson and Towns 2005). The fur on the back of all four invasive rodents can be brown (agouti); however, the only species of the four invasive rodents in the Pacific that includes some individuals with black fur on their backs is $R$. rattus (Tomich 1986, Atkinson and Towns 2005).

\section{DIET}

The diet of $R$. rattus in the Pacific has been well studied using a variety of methods, including examination of stomach contents (Kami 1966, Yabe 1979, Clark 1981, Sugihara 1997, Cole et al. 2000, Sweetapple and Nugent 2007, Caut et al. 2008a), field observations of chewed food items (Norman 1970, Meyer and Shiels 2009, Pender et al. 2013), field trials measuring food item removal (Norman 1970, Abe 2007, Shiels and Drake 2011), captive-feeding trials (Amarasakare 1994, Williams et al. 2000, Pérez et al. 2008, Gregory and Macdonald 2009, Meyer and Shiels 2009, Shiels 2011), and stable isotope analysis (Harper 2006, Caut et al. 2008a,b, Shiels et al. 2013). As a whole, these dietary assessments confirm that $R$. rattus is highly omnivorous, eating a wide variety of plants, invertebrates, vertebrates, and fungi (Figure 3).

Based on literature reviewed from Pacific islands, Figure 3 summarizes the relative im- 


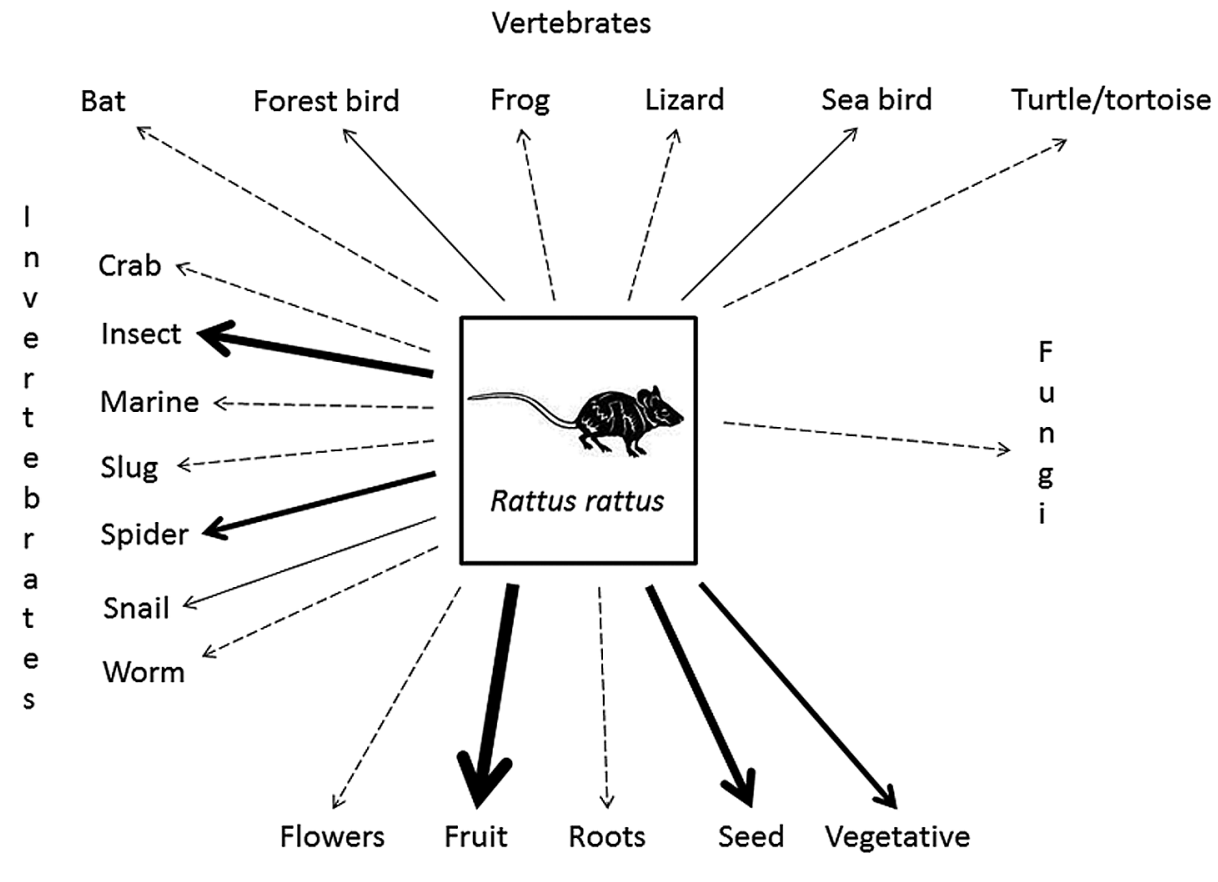

Plants

Figure 3. Organisms that Rattus rattus are known to consume on Pacific islands. The arrows' thickness indicates the average diet of $R$. rattus on Pacific islands, measured by the relative proportion of the food item in stomach contents and in some cases other indicators of diet (see text); dashed lines indicate items that have been recorded but are least common in diets. In general, thickened solid arrows = common consumption of food item; thinnest solid arrows = generally infrequent by volume but commonly consumed on some islands (i.e., snail, forest bird, seabird); dashed arrows $=$ uncommon consumption of food item (i.e., infrequent in most studies and islands). The vegetative category includes stems and leaves. All categories and relationships are based on reviewed literature (see text and Figure 4).

portance of various food items in the diet of $R$. rattus. The most frequent food items consumed by $R$. rattus are plants (fruit, seed, vegetative), insects, and spiders; yet most of the terrestrial food web may be vulnerable to $R$. rattus consumption. By collating available stomach content analyses of $R$. rattus across the insular Pacific ( $n=20$ sites) and determining the ratio of plant to animal contents in their diets (based on mass or volume), we found that plant material dominated the diet of $R$. rattus at 17 of 20 sites (Figure 4), and plants were generally nine times more frequent in its diet than animals (i.e., average ratio in Figure 4 is $9: 1$ ). The three sites where animals were proportionally more frequent than plants in the diet of $R$. rattus (i.e., ratio was $<1.0)$ included two sites at the highest latitudes sampled $\left(47^{\circ} \mathrm{S}\right)$ and one at $38^{\circ} \mathrm{S}$ (Figure 4).

Plant material often composes $75 \%-80 \%$ of the diet of $R$. rattus in the insular Pacific (Kami 1966, Norman 1970, Yabe 1979, Clark 1981, Cole et al. 2000, Beard and Pitt 2006, Sweetapple and Nugent 2007, Shiels et al. 2013), and fruit and seed are the most common plant items in their diet (see review by Grant-Hoffman and Barboza [2010] and Figure 3). After a literature review, GrantHoffman and Barboza (2010) found that 36 plant families have been documented containing species consumed by $R$. rattus, and the majority of these families had the fruit as the plant part that rats consumed. Clark (1982) found that one population of $R$. rattus in the Galápagos Islands consumed at least 22 


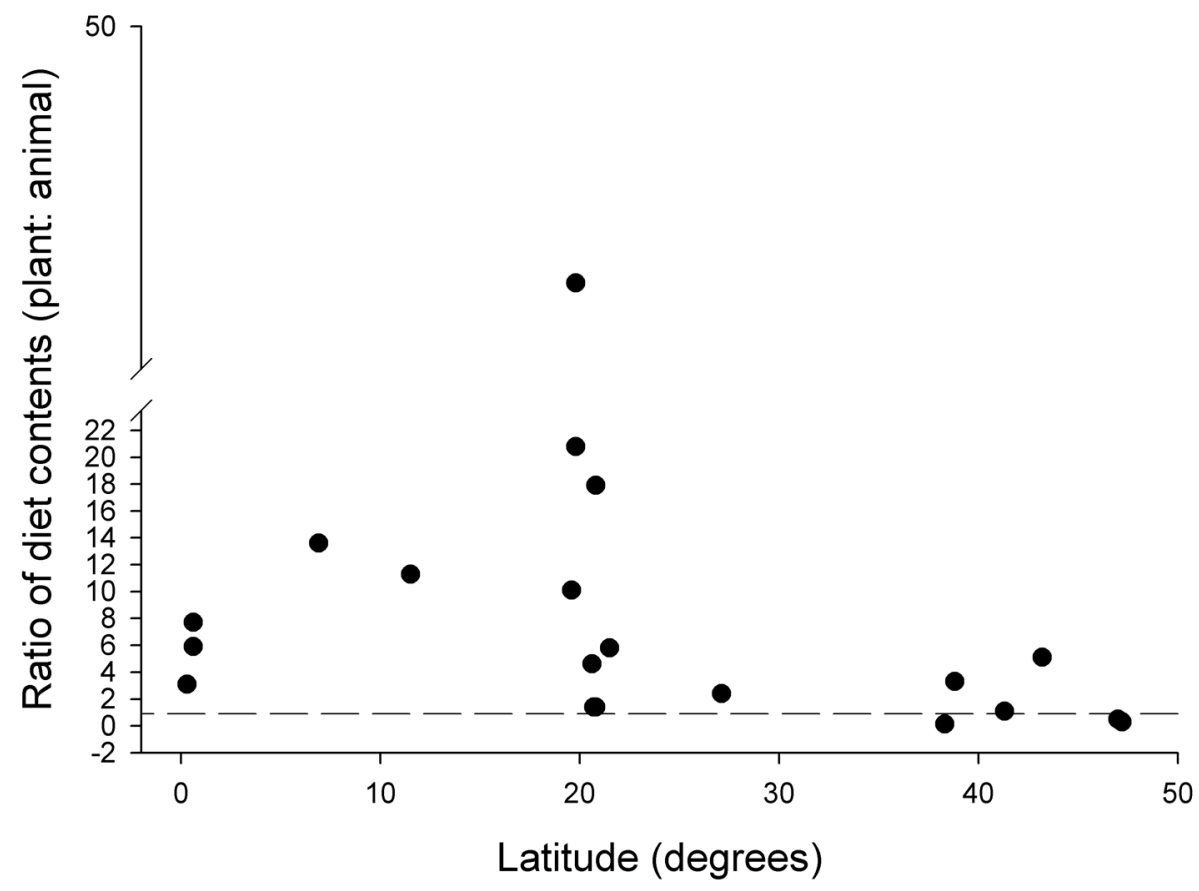

Figure 4. Ratio of plant to animal contents in the diet of $R$. rattus trapped on Pacific islands. The dashed horizontal line represents the $1: 1$ line where the plant component of the rat diet is equal to the animal component (i.e., a diet of $50 \%$ plant, $50 \%$ animal). Diets are based on mass or volumetric quantities from stomach content analyses. Twenty entries from 14 islands in the Pacific are shown. The three points below the $1: 1$ line (latitudes $38.8^{\circ} \mathrm{S}, 47.0^{\circ} \mathrm{S}$, and $47.2^{\circ} \mathrm{S}$, each from New Zealand) indicate the only studies where $R$. rattus diets contained proportionally greater amounts of animal than plant contents. Data are from Strecker and Jackson (1962), Kami (1966), Norman (1970), Fall et al. (1971), Daniel (1973), Clout (1980), Clark (1981), Gales (1982), Tobin et al. (1994), Sugihara (1997), Robinet et al. (1998), Cole et al. (2000), Beard and Pitt (2006), Harper (2007), Sweetapple and Nugent (2007), Yabe et al. (2009), Shiels et al. (2013).

species of vascular plants. In Hawai' $i$, the relative abundance of fruit in $R$. rattus stomachs was $55 \%$ in mesic forest (Shiels et al. 2013), $23 \%-53 \%$ in wet forest (Sugihara 1997), and $44 \%$ in arid shrubland (Cole et al. 2000). Fruit fragments of Clidemia birta, Rubus rosifolius, and Psidium cattleianum, which are all invasive species on many Pacific islands, were found in $R$. rattus trapped on $\mathrm{O}^{\prime}$ ahu (Shiels et al. 2013), and Clidemia birta and Rubus rosifolius were found in R. rattus trapped on Hawai'i Island (Beard and Pitt 2006). Fruit composed $26 \%$ of the stomach contents of $R$. rattus trapped in a New Zealand forest, which included 12 native species, and Eleaocarpus bookerianus was the most abundant species, composing $13 \%$ of the stomach contents (Sweetapple and Nugent 2007). Ripe fruit is most commonly eaten by rats; however, green (immature) fruit of a variety of coastal species including coconut (Cocos nucifera) and some high-elevation legume fruits and seeds ( $S_{0-}$ phora chrysophylla) are often consumed by $R$. rattus in the Pacific (Marshall 1955, Fall et al. 1971, Amarasekare 1994).

Seed consumption by $R$. rattus is generally an antagonistic relationship (seed predation), yet some intact seeds are found in stomach contents (see Shiels et al. 2013) and can survive gut passage and therefore represent a mutualistic relationship (seed dispersal) with plants (Williams et al. 2000, Shiels 2011, Shiels and Drake 2011) (see subsection on Impact on Plant Communities). Seeds of multiple species of the native Hawaiian palm Pritchardia are commonly depredated by $R$. 
rattus (Pérez et al. 2008), and several other native trees in Hawai'i also suffer $R$. rattus seed predation (Shiels and Drake 2011). In a New Zealand forest, seed fragments were the dominant food item in adult $R$. rattus stomach contents, composing $48 \%$ of their total diet (Sweetapple and Nugent 2007), whereas in a Hawaiian forest approximately $25 \%$ of the stomach contents were seed fragments (Shiels et al. 2013). Many seeds of economically important species (e.g., macadamia nuts [Macadamia integrifolia and M. tetraphylla] and coconuts) are consumed by $R$. rattus in the Pacific and can form the dominant parts of their diets (Fall et al. 1971, Twibell 1973, Tobin et al. 1994, Sugihara 2002, Elmouttie and Wilson 2005). Flowers are not commonly consumed by $R$. rattus (Sweetapple and Nugent 2007), yet in arid habitats in the Galápagos Islands flowers were occasionally found in $R$. rattus stomachs (Clark 1981); in southern Tasmania $R$. rattus foraged on Acrotriche serrulata flowers (Johnson et al. 2011), and rats (probably $R$. rattus) in Hawai'i consumed Freycinetia arborea inflorescenses (Drake et al. 2011) and destroyed some Clermontia fauriei flowers while presumably accessing nectar (D. Drake, unpubl. data).

In general, vegetative material (e.g., seedlings, leaves, and shoots) is less abundant than fruit and seed in $R$. rattus diet. However, in some environments and seasons, vegetative material can account for a substantial portion $(20 \%-30 \%)$ of a fruit-dominated diet (Kami 1966, Norman 1970, Clark 1981, Cole et al. 2000). The pith tissue in twigs of 23 plant species is consumed by $R$. rattus when fruit production is low in the Ogasawara Islands, Japan (Yabe et al. 2010, Abe and Umeno 2011). Rats (probably $R$. rattus) also wound legume trees (Acacia koa) in Hawai' $\mathrm{i}$ in young ( $<6$ yr old) but not old (7- to 11 -yr-old) plantations by stripping the bark (Scowcroft and Sakai 1984); they also eat Clermontia fauriei bark in wet forest on Kaua'i (D. Drake, unpubl. data). In addition, Campbell (1978) found that $R$. rattus ate the bark on two species of Araliaceae (Pseudopanax arboreus and Schefflera digitata), and they ate leaves, stems, and roots of a third species in this family (Stilbocarpa lyallii). Sugihara (1997) found that leaves, stems, roots, and rhizomes could compose $2 \%-28 \%$ of $R$. rattus diet on Maui, and the greatest abundance of these vegetative components occurred in rat stomachs during the summer. Clark (1982) found that fern rhizomes (Blechnum sp.) were a frequent component in most $R$. rattus stomachs from montane forest in the Galápagos Islands; and leaves from 24 species were found in stomachs analyzed across eight $R$. rattus populations (Clark 1981). Moss was also present in $R$. rattus diets in Hawaiian macadamia nut orchards and in New Zealand forests, although it accounted for a very small $(1 \%-4 \%)$ portion of their diet (Tobin et al. 1994, Sweetapple and Nugent 2007). In general, vegetative parts are most commonly consumed by $R$. rattus when other food types are limited.

Fungus is an additional component of $R$. rattus diet, and it has generally been identified in stomachs from cool and moist temperate islands, such as North Island, New Zealand, and Stewart Island, New Zealand, where it composed $<2 \%$ of $R$. rattus diet (Daniel 1973, Gales 1982, Sweetapple and Nugent 2007), and on offshore islands of Tasmania where partly eaten Agaricus campestris and Lepiota rhacodes were documented (Norman 1970). Winter sampling of $R$. rattus stomachs revealed relatively high (12\%) fungi content in pine (Pinus radiata) plantation forest in New Zealand (Clout 1980). In montane forest in the tropical Galápagos Islands, fungi composed up to $12 \%$ of the $R$. rattus seasonal diet (Clark 1981). In addition, fungi dispersal may be enhanced by gut passage of fungal spores (Vernes and Dunn 2009, Vernes and McGrath 2009).

Arthropods, particularly insects, are an important dietary component of most $R$. rattus individuals, but they typically compose a smaller component of the $R$. rattus diet relative to plant material (Kami 1966, Norman 1970, Yabe 1979, Clark 1981, Cole et al. 2000, Sweetapple and Nugent 2007, Shiels et al. 2013) (Figures 3, 4). For example, arthropods composed $14 \%-16 \%$ of $R$. rattus stomach contents in Tasmania, Maui, and O'ahu (Norman 1970, Cole et al. 2000, Shiels et al. 2013) and just $2 \%$ in stomachs in lowland wet forest in Hawai'i (Beard and Pitt 2006). 
However, insects dominated $R$. rattus diets on some high-latitude islands, such as Stewart Island and Taukihepa Island (Big South Cape Island), New Zealand ( $47^{\circ} \mathrm{S}$ latitude) (Gales 1982, Harper 2007). In addition, seasonality and rat age and sex can influence the abundance of arthropods eaten (Clark 1982, Miller and Miller 1995, Sugihara 1997, Caut et al. 2008a). Clout (1980) attributed the dominance of arthropods (particularly Lepidoptera and weta [Rhaphidophoridae]) in $R$. rattus diet to winter scarcity of fruit and seed. The tree weta, Hemideina thoracica, was a yearround prey item for $R$. rattus in New Zealand broadleaf forest and composed $26 \%$ of their annual diet (Daniel 1973). Clark (1982) in the Galápagos and Gales (1982) on Stewart Island found that young rats ate more arthropods than did adult rats, which may indicate a greater protein demand for growing animals. Similarly, Gales (1982) found that mature females consumed more birds and arthropods than did males, which may reflect a protein demand for reproduction. Beetles (Coleoptera) and crickets (Orthoptera) were common components of $R$. rattus diets in New Zealand (Innes 2005a, Ruscoe and Murphy 2005, St. Clair 2011) and Hawai'i, and $11 \%-42 \%$ of the $R$. rattus stomachs sampled in Hawai' $i$ also contained spiders (Araneae) (Cole et al. 2000, Shiels et al. 2013). Caterpillars appear to be an attractive food item for $R$. rattus, but their proportion of total stomach contents can differ widely among sites (e.g., $25 \%$ in montane Maui [Cole et al. 2000]; 3\% in montane O'ahu [Shiels et al. 2013]).

Earthworms (Norman 1970, Clark 1980, Copson 1986, Sugihara 1997), terrestrial mollusks (St. Clair 2011), and crabs (Fall et al. 1971, Wegmann 2009) (Figure 5) are components of the $R$. rattus diet on some Pacific islands (Figure 3). Because some food items (e.g., egg yolk, blood, nectar, soft tissues) are not easily identifiable via standard stomach content analyses, captive feeding trials provide another useful technique for determining rat diets. Under captive feeding conditions, $R$. rattus fed on ghost crabs (Ocypode sp.), which occupy sandy shorelines on many tropical Pacific islands (Jackson and Carpenter 1966 cited in Fall et al. 1971). In Hawai'i, two non- native invasive snails, Achatina fulica and Euglandina rosea, were readily consumed by $R$. rattus during captive feeding trials (Meyer and Shiels 2009). Introduced slugs were also consumed by $R$. rattus in New Zealand (Miller and Miller 1995) and in captive feeding trials in Hawai' $\mathrm{i}$, yet not to the extent observed in consumption of introduced snails (A.B.S. and S. Joe, unpubl. data). Several studies indicate that various bird eggs (seabirds and forest birds) are consumed by $R$. rattus, and the sizes of the eggs appear to influence the likelihood of consumption (Norman 1970, Amarasekare 1994, Igual et al. 2006, Zarzoso-Lacoste et al. 2011). Because rats generally consume little if any of the shell when eggs or snails are eaten (Amarasekare 1993, Caut et al. 2008a, Meyer and Shiels 2009) or exoskeletons when crabs are eaten (Fall et al. 1971), captive feeding trials are often needed to complement other means of assessing the importance of such prey in diets of $R$. rattus.

In addition to bird eggs, feathers in $R$. rattus stomachs are evidence that either juvenile or adult birds have been consumed directly or scavenged (Clark 1981, Harper 2007, Sweetapple and Nugent 2007). Caut et al. (2008a) found that approximately half of the $R$. rattus stomachs analyzed ( $n=9$ of 16 stomachs) had seabird feathers on an isolated New Caledonian island during the seabird nesting season; yet there was no evidence of seabirds in rat stomachs during the nonnesting season. On Higashijima, Ogasawara Islands, 28\% of the stomach contents of $R$. rattus were seabirds, particularly the Bulwer's Petrel (Bulweria bulwerii, 78-130 g [Yabe et al. 2009]). Forest birds typically compose $<9 \%$ of $R$. rattus stomach contents (Gales 1982, Harper 2007, Sweetapple and Nugent 2007), and birds may be absent from $R$. rattus stomach contents even in forests where both native and nonnative birds are present (Sugihara 1997, Shiels et al. 2013). It should be noted that some animals, such as large seabirds (Norman 1970; e.g., Sula spp. in Caut et al. 2008a), goats (Capra bircus), burros (Equus asinus), and other rodents, appear in $R$. rattus stomachs from scavenging rather than direct predation (Clark 1981).

Rattus rattus has been observed killing hatchlings of the giant Galápagos tortoise 


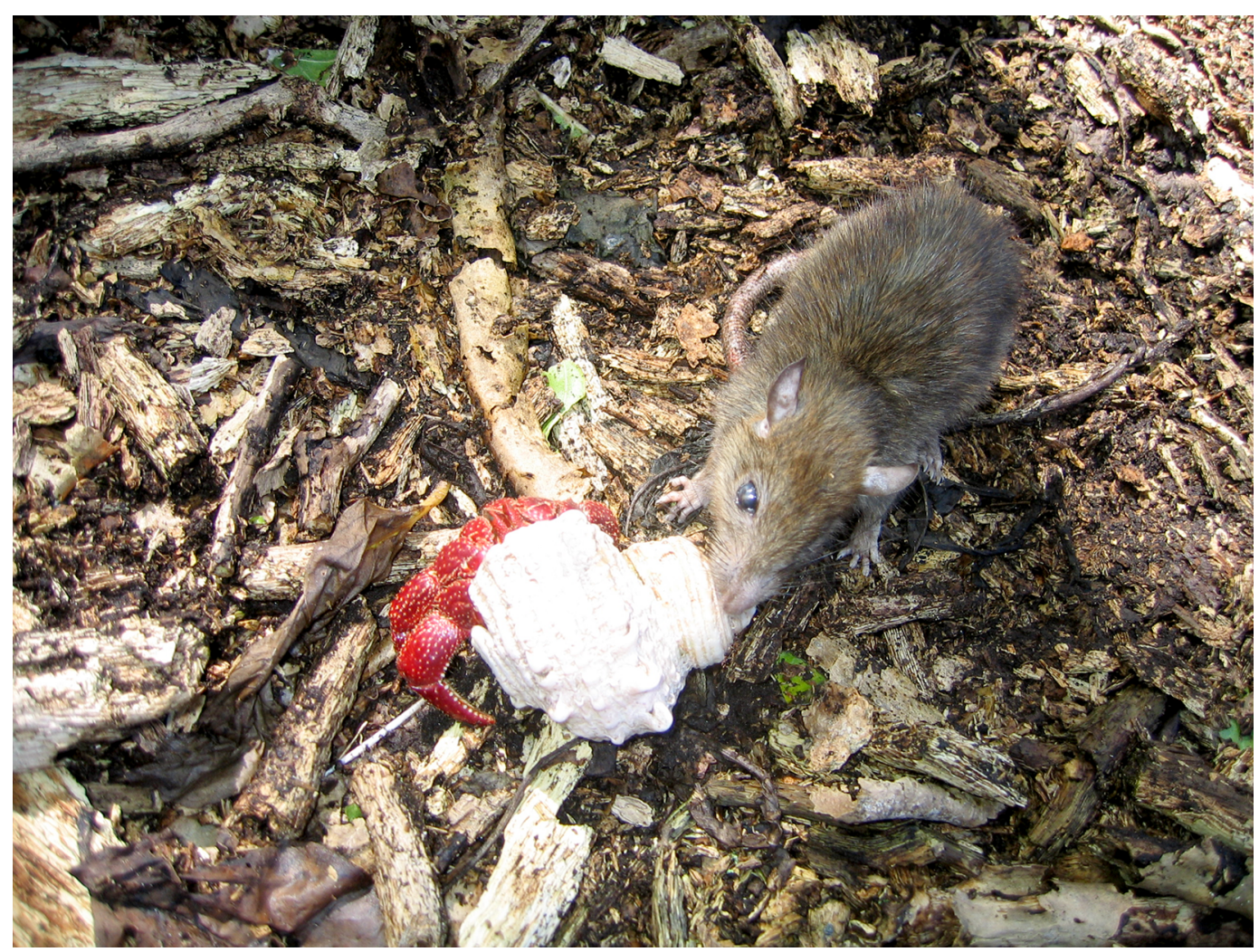

Figure 5. Rattus rattus interacting with a strawberry hermit crab (Coenobita perlatus) on Palmyra Atoll. (Photograph courtesy of A. S. Wegmann.)

(Geochelone elephantopus [Clark 1981]) and green sea turtle (Chelonia mydas [Caut et al. $2008 a]$ ), even though there was no evidence of these vertebrates in the rat stomachs analyzed at those sites. Gnawed eggshells of Royal Penguin (Eudyptes schlegeli) were found in coastal tussock grasslands of Macquarie Island where $R$. rattus occur (Pye et al. 1999). Skinks were found in $<10 \%$ of $R$. rattus stomachs in New Caledonia (Caut et al. 2008a) and Tasmania (Norman 1970), and remnants of a lizard were uncovered in a $R$. rattus stomach in Borneo (Harrison 1954 cited in Fall et al. 1971). Both lizards (Tropidurus duncanensis) and geckos (Phyllodactylus galapagensis) were found in $R$. rattus stomachs in arid habitats in the Galápagos, but they never accounted for more than $3 \%$ of the average stomach contents (Clark 1981). Bats, frogs, and snakes are potential food items of $R$. rattus, but studies documenting consumption of these food types in the Pacific are largely lacking. The Pacific boa (Candoia bibroni) coexists with $R$. rattus in Southwest Pacific forests, yet $R$. rattus stomach contents did not reveal any evidence of snakes (Robinet et al. 1998). However, the milk snake (Lampropeltis triangulum) "reappeared" 2 yr after $R$. rattus removal from San Pedro Mártir Island off Baja Peninsula, Mexico (Samaniego-Herrera et al. 2011), and there is reference to $R$. rattus in the Caribbean nearly causing the extinction of an endemic racer snake (Towns 2009). Beard and Pitt (2006) did not find any evidence of Eleutherodactylus coqui frogs in $R$. rattus stomachs in Hawaiian rain forest, yet $R$. rattus has been observed consuming E. coqui in Puerto Rican rain forest (Stewart and Woolbright 1996). 
Two species of bats (greater short-tailed, Mystacina robusta, and lesser short-tailed, $M$. tuberculata) went extinct on Taukihepa Island, New Zealand, after $R$. rattus was introduced (Daniel 1990), yet documentation of bats in $R$. rattus dietary studies across the Pacific is absent. Rattus rattus has been documented foraging in the intertidal zone in several locations in the Pacific, including Chile and Midway Atoll, but the types of marine organisms and the extent to which they prey upon them is unknown (Carlton and Hodder 2003). Although some prey species are infrequent or minimally represented in $R$. rattus diets, it is possible that such prey may still suffer population-level changes from $R$. rattus that result from relatively rare consumption (e.g., VanderWerf 2001).

\section{ECONOMIC IMPORTANCE AND \\ ENVIRONMENTAL IMPACTS}

Much of the economic impact resulting from $R$. rattus populations relates to agricultural and horticultural damage; they can destroy up to $30 \%$ of crops annually (Hood et al. 1971, Elmouttie and Wilson 2005) and spoil foods that result in millions of dollars of losses each year for islands or island chains (Sugihara 2002, Pimentel et al. 2005). Disease transfer to humans and alteration of native habitats are additional negative aspects of $R$. rattus invasions. It can be difficult to determine impacts of $R$. rattus unambiguously without experimental studies because additional rodent species and/or other animals with overlapping diets are often sympatric with $R$. rattus. Therefore, studies that have implicated $R$. rattus in damaging species and habitats by use of correlative factors should be interpreted with caution. Knowing the breadth of organisms that $R$. rattus consumes (e.g., from dietary studies) is an important first step toward determining their environmental impacts or the ecosystem changes that result from $R$. rattus behaviors. However, all interested parties (e.g., agriculturalists, academics, conservationists, natural historians, or land managers) will benefit greatly if causal factors can be identified and linked to $R$. rattus' environmental impacts. For example, it would be valuable to know why some birds and plants are highly at risk to predation by $R$. rattus when other species appear to be unaffected.

\section{Direct and Indirect Impacts}

Rattus rattus can have both direct and indirect effects on native biota. Many of the direct impacts have been reported in the preceding diet section. A growing body of evidence of indirect effects of rats on island ecosystems is reported from a group of 18 offshore islands in northern New Zealand, where half of the islands were rat-free at the time of the study (Fukami et al. 2006, Wardle et al. 2007, 2009, Mulder et al. 2009, Towns et al. 2009, Peay et al. 2013). The main conclusions from these studies were that islands with rats (R. rattus, $R$. exulans, and $R$. norvegicus) had few seabirds present (presumably because the rats ate the seabirds), which caused reduced inputs of seabird-transferred marine nutrients and subsequent changes in soil fauna, fungi, decomposition, and plant nutrient concentrations (Fukami et al. 2006, Wardle et al. 2007, 2009, Mulder et al. 2009, Towns et al. 2009, Peay et al. 2013). The extent to which $R$. rattus (versus other rodent species) was involved in these ecosystem-level changes to New Zealand islands is unclear, yet $R$. rattus is certainly capable of such changes given direct evidence of predation on burrowing seabirds on islands (Jones et al. 2008). Additional indirect effects of rats include competition for various food items. For example, birds that rely on either arthropods or fruit may suffer from resource competition by $R$. rattus in areas where these animals have overlapping diets.

\section{Impact on Plant Communities}

The impacts of $R$. rattus on plant communities can be difficult to determine because of the substantial time lag between effects on seeds and seedlings and the responses of adult plant populations. Such lag times are particularly relevant for longer-lived plants like trees. Some responses to $R$. rattus impacts may mask others, particularly over extended periods, which makes the species composition of the community potentially important for assess- 
ing rat impacts. For these reasons, assessments of plant community change as a result of $R$. rattus are generally restricted to their effects on seeds and seedlings (Shaw et al. 2005, Abe 2007, Wegmann 2009, Auld et al. 2010, Shiels and Drake 2011).

Seed removal in field trials is an important step in determining seed fate, and several characteristics of the seeds (e.g., size, nutritional value, and defense chemicals) can affect seed removal by rodents (Forget et al. 2005). Rattus rattus individuals remove and eat fruit, including seed, on the ground and in the canopy (Auld et al. 2010, Shiels and Drake 2011, Pender et al. 2013). As indicated by a recent literature review of plant reproductive parts (i.e., fruit, cone, seed) consumed by $R$. rattus, the small parts $(<15 \mathrm{~mm}$, but especially $5-10$ $\mathrm{mm})$ were the most frequently consumed (Grant-Hoffman and Barboza 2010). Shiels and Drake (2011) found that the three largest seeds (17.9-30.3 $\mathrm{mm}$ longest axial length) monitored in the field were among the most unattractive to $R$. rattus, whereas intermediate-sized seeds $(5.2-17.7 \mathrm{~mm})$ suffered the highest level of predation $(>50 \%)$, and the smallest seeds $(0.5-1.2 \mathrm{~mm})$ were ingested but not destroyed. On Lord Howe Island, Auld et al. (2010) found that $R$. rattus removed $94 \%$ of Lepidorrhachis mooreana palm fruit from trees, but a sympatric palm (Hedyscepe canterburyana) that has fruits 18 times larger in dry mass suffered much less (54\%) removal by $R$. rattus. Pender et al. (2013) showed that trapping $R$. rattus in a Hawaiian forest resulted in the reduction of fruit consumption and seed predation from $46 \%$ to just 4\% for the endangered tree Cyanea superba. In Hong Kong, Hau (1997) concluded that forest restoration by direct seeding would not be feasible due to rat (R. rattus and Niviventer fulvescens) predation of 12 plant species. Yamashita et al. (2003) suggested that $R$. rattus may be facilitating the invasion of the nonnative tree Bischofia javanica in the Ogasawara Islands because $R$. rattus depredates the seeds of the dominant native tree Elaeocarpus photiniae-folius both before dispersal (27\%$33 \%$ of the seed crop) and after dispersal $(41 \%-100 \%)$. Several other studies of fruit and seed removal have occurred on Pacific is- lands that include $R$. rattus as part of the rodent community, but the particular rodent species responsible for such removals were not identified (e.g., Moles and Drake 1999, Uowolo and Denslow 2008, Meyer and Butaud 2009, Erwin and Young 2010, GrantHoffman et al. 2010, Chimera and Drake 2011).

Evidence of rat-gnawed seeds is commonly found in habitats where $R$. rattus has invaded; the spatial distribution of such rat-gnawed seeds is often clumped due to their presence in "husking stations," which are sheltered areas where rats process food items after collection (McConkey et al. 2003, Elmouttie and Wilson 2005, Wegmann 2009) (Figure 6). Rats may use husking stations to hide from predators or competitors while they consume food items (Campbell et al. 1984). Rattus rattus generally does not cache or store foods; however, excess cereal bait was cached by $R$. rattus held in $5 \times 5 \times 2 \mathrm{~m}$ pens (Morriss et al. 2012), and at the edge of their latitudinal distribution $\left(55^{\circ} \mathrm{S}\right.$ [Macquarie Island]) Shaw et al. (2005) found that on average $30 \mathrm{~g}$ of fruit (equivalent to 20,000-30,000 fruit and seed) of the megaherb Pleurophyllum bookeri were frequently stored by $R$. rattus in small $(20 \times 20 \mathrm{~cm})$ piles on the surface just before winter. The number of seedlings and adult plants that originate from intact seeds deposited in husking stations is rarely known. However, due to the characteristic substrates of husking stations (e.g., rock piles, root and tree bases), they are often unsuitable sites for germination and plant establishment from intact seeds that are left by rats.

Kukui nut (Aleurites moluccana) is a common tree in tropical Pacific island forests, and the hard seed coats are often found in husking stations and valley bottoms with distinct markings of rat gnawing (McConkey et al. 2003, Shiels and Drake 2011). It is interesting that both field and laboratory trials in which $A$. moluccana fruit and seed were offered to $R$. rattus revealed that it was not an attractive food item (Shiels 2011, Shiels and Drake 2011). One explanation for this enigma is that consumption of $A$. moluccana in the field may be overestimated because the stony seed coats of the chewed seeds persist indefinitely on the 


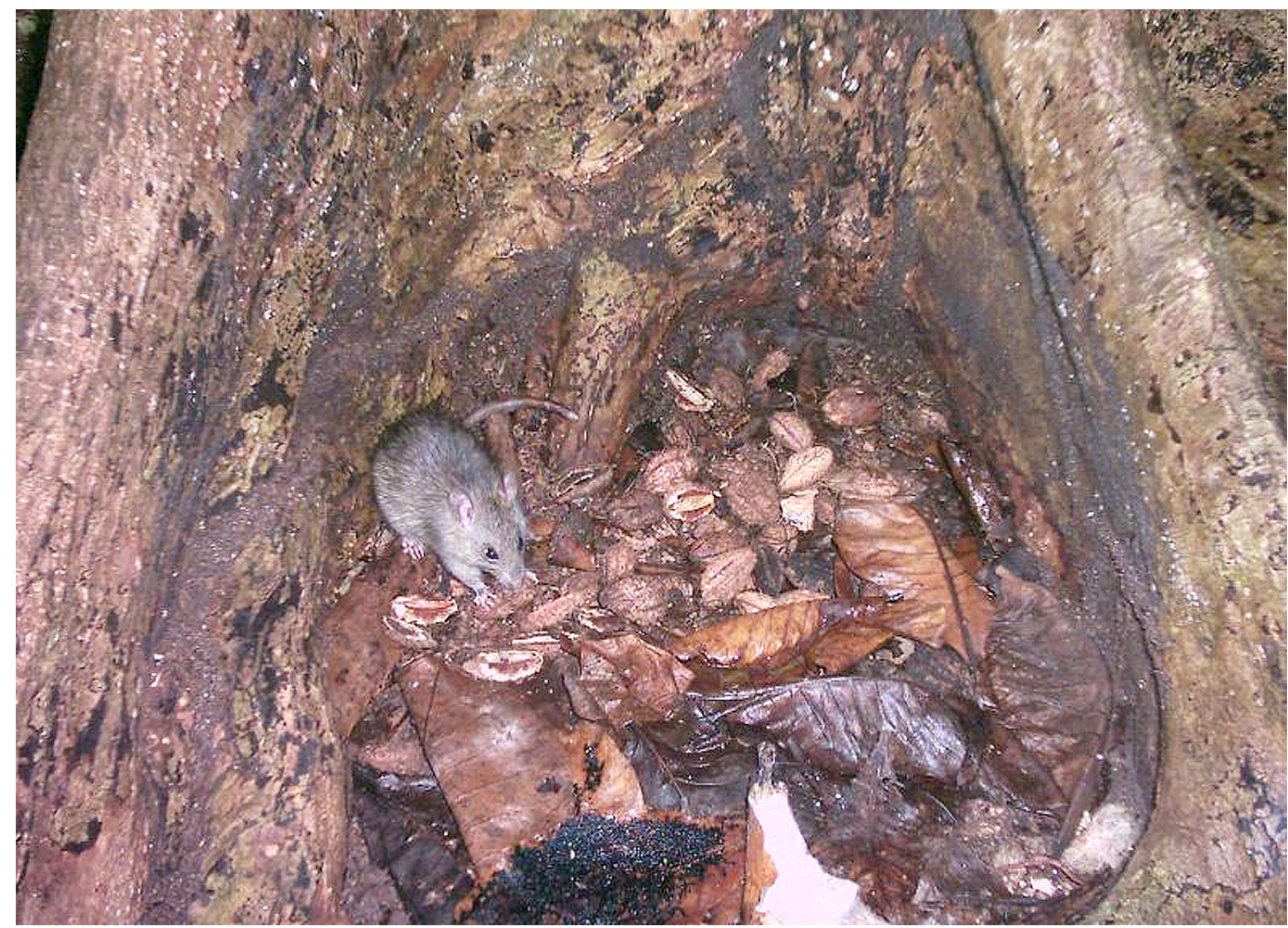

FIgURE 6. Rattus rattus processing the fruit and seed of Terminalia catappa in a husking station at the base of a tree on Palmyra Atoll. Note the many discarded husks (seed coverings) on the ground surrounding the rat. Food items are typically discarded at individual husking stations over a period of many days. (Photograph courtesy of A. S. Wegmann.)

forest floor (Shiels 2011). An additional explanation for the presence of chewed $A$. moluccana seeds may be that rats target the very hard and readily available $A$. moluccana seeds to grind or sharpen their teeth. Extending prior captive feeding trials with $R$. rattus and A. moluccana (Shiels 2011, Shiels and Drake 2011) showed that several $R$. rattus gnawed the seed coats without penetrating them (A.B.S., unpubl. data). Thus, seeds of $A$. moluccana do not appear to be a favored food for rats (particularly $R$. rattus [Shiels 2011, Shiels and Drake 2011]); it may be a "famine food" or simply a hard item that enables rats to grind their incisor teeth to sharpen and maintain them.

Rattus rattus disperses some seeds of both native and nonnative species, as demonstrated in the Galápagos (Clark 1980), Hawai'i (Shiels
2011, Shiels and Drake 2011), New Zealand (Williams et al. 2000), and the Ogasawara Islands (Abe 2007). The majority of the seeds that are dispersed by $R$. rattus are small $(<1.5-2.2 \mathrm{~mm})$ and survive ingestion and gut passage (Williams et al. 2000, Shiels 2011). In addition, larger-seeded species $(>2.5 \mathrm{~mm}$ long) may also be dispersed by $R$. rattus by transporting collected seeds and then failing to eat them (Abe 2007, Shiels and Drake 2011). Such dispersal of native species could be particularly important for plant community change if there are no longer native frugivores to disperse large-seeded, fleshy fruited species, such as the Hawaiian forest species Planchonella sandwicensis (syn. Pouteria sandwicensis), which has seeds that are $18 \mathrm{~mm}$ in length and are sometimes dispersed by $R$. rattus (Shiels and Drake 2011). 
Future studies that will extend our understanding of $R$. rattus effects at the seed stage to the seedling stage will also help clarify the ultimate impacts of $R$. rattus on plant communities. For example, on subantarctic Macquarie Island, Shaw et al. (2005) found that $R$. rattus reduced initial seedling establishment and seedling survival of the megaherb Pleurophyllum hookeri, yet high seedling mortality in areas protected from $R$. rattus for 1 yr resulted in an absence of sustained impacts on seedling densities. It is more common for $R$. rattus to consume seeds than seedlings (GrantHoffman and Barboza 2010). However, on Palmyra Atoll where both $R$. rattus and landcrab densities were particularly high $(>50$ individuals/ha), $R$. rattus killed $63 \%$ of monitored seedlings of five native species (Wegmann 2009).

\section{Impact on Vertebrate Communities}

Vertebrate species, such as turtles, tortoises, lizards, and bats, are prey items of $R$. rattus, as evidenced by diet assessments or observations (Clark 1981, Daniel 1990, Caut et al. 2008a [see section on Diet]); however, the community-level impacts of this consumption have yet to be investigated. The threat of predation by rats on birds seemingly attracts more attention than threats posed to any other type of rat prey. With the strong climbing capabilities of $R$. rattus, few predators pose a greater threat to insular forest birds. Some seabirds are also at risk from $R$. rattus, particularly at the egg and chick life stages, yet many other vertebrate predators also threaten seabirds of all life stages and these other species can be more successful seabird predators than rats (see Mulder et al. 2011).

Forest and wetland birds have suffered substantial predation and extinction from $R$. rattus (Towns et al. 2006). Five species of birds (saddleback, Philesturnus carunculatus; robin, Petroica australis; fernbird, Bowdleria punctate; banded rail, Rallus philippensis; snipe, Coenocorypha iredalei; and bush wren, Xenicus longipes) went extinct following $R$. rattus invasion of Taukihepa Island, New Zealand (Bell 1978, Atkinson 1989, Towns et al. 2006). Also in the southern Pacific, five endemic forest birds on Lord Howe Island went extinct during the years after a shipwreck occurred and $R$. rattus colonized the island (Towns 2009). Rattus rattus is thought to be the primary factor in the extinction of the translocated populations of Laysan Rail (Porzana palmeri) and Laysan Finch (Telespiza cantans) on Midway Atoll (Fisher and Baldwin 1946, Seto and Conant 1996). Similarly, translocating an endangered parakeet (Eunymphicus cornutus uvaeensis) was deemed unfeasible in New Caledonian islands because of $R$. rattus nest predation of eggs (Robinet et al. 1998). Rattus rattus predation of robin (Petroica australis) eggs and chicks was observed directly by automated cameras on North Island, New Zealand (Brown 1997); in Australia, cameras linked $96 \%$ of predation events at artificial nests and eggs to $R$. rattus (Major and Gowing 1994), and R. rattus was also documented removing chicks from nests (Major 1991). Similarly, photographic evidence revealed that $R$. rattus was the only nest predator of an endangered flycatcher (the 'elepaio, Chasiempis

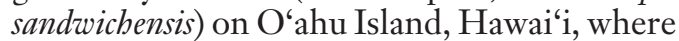
it reduced nest success by $45 \%-55 \%$ (VanderWerf 2001). In high elevations (2,100-2,500 $\mathrm{m})$ in Hawai'i, nest predation by $R$. rattus was just 4\% ( $n=500$ artificial nests), which may be due to low rat densities $(<1$ individual/ha) or high abundance of alternative foods (plants and arthropods [Amarasekare 1993]). Amarasekare (1994) offered captive $R$. rattus different-sized bird eggs as proxies for native Hawaiian bird eggs. All but the largest eggs (Japanese quail, Coturnix coturnix; $25 \times 40$ $\mathrm{mm}$ ) were eaten by the rats, implying that some native bird eggs (e.g., endangered palila, Loxioides bailleui; $16.8 \times 25 \mathrm{~mm}$ ) would be consumed by $R$. rattus. Using rat-control methods to reduce $R$. rattus abundance, 'elepaio reproduction increased $112 \%$, and the population growth rate (lambda) increased from 0.76 to 1.00 (VanderWerf and Smith 2002). Furthermore, long-term (15 yr) nest monitoring of 'elepaio in Hawaiian forests revealed the importance of nest height in forest invaded by $R$. rattus; nests $\leq 3 \mathrm{~m}$ in height produced offspring less often than nests positioned higher in the canopy (VanderWerf 2012). Nesting height may therefore be one 
useful factor for determining forest bird vulnerability to $R$. rattus.

The effects of $R$. rattus on seabirds are more variable than those on native forest birds; some seabirds are highly vulnerable, whereas others appear largely unaffected by presence of $R$. rattus (Jones et al. 2008, Ruffino et al. 2009). In a Mediterranean-wide analysis of historical data sets that included four seabird species (three shearwaters that were each $>350 \mathrm{~g}$, and one petrel weighing 25-29 g), only the smallest species (the Storm Petrel, Hydrobates pelagicus) appeared to have its abundance limited by $R$. rattus (Ruffino et al. 2009). Jones et al. (2008) conducted a global meta-analysis on the effects of introduced rats on seabirds and found that $R$. rattus was the invasive rat that had the largest negative effect on seabirds, thus surpassing $R$. norvegicus and $R$. exulans in frequency of seabird predation. Furthermore, R. rattus had the largest effect on burrowing seabirds (22 species preyed upon), followed by groundnesting (12 species), those nesting in holes and crevices (six species), and branch-nesting (one species) (Jones et al. 2008). One caution with global generalizations about seabird vulnerability to $R$. rattus is that most knowledge about the impacts of introduced rats on seabirds is from temperate ecosystems (e.g., only five of 115 studies in Jones et al. [2008] were from tropical regions).

Examples of seabird mortality on Pacific islands are also largely limited to temperate regions. On Anacapa Island, California, $R$. rattus removal resulted in pronounced artificial nest success of Xantus' Murrelet (Synthliboramphus bypoleucus scrippsi); $96 \%$ of artificial eggs that mimicked eggs of this small seabird (148-167 g) were depredated before eradication, and just $3 \%$ of eggs were depredated (probably by gulls and ravens) after eradication (Jones et al. 2006). Harper (2007) monitored nests of a burrowing seabird, the Sooty Tern (Puffinus griseus; $800 \mathrm{~g}$ ), on Taukihepa, New Zealand, in areas where $R$. rattus and weka (an introduced large rail, Gallirallus australis) were trapped and in sites where they were not trapped to determine the effects of each of these predators on nest successes of sooty terns. Weka were the primary predators of sooty terns chicks (90-150 g), and about $40 \%$ of their stomach contents was sooty terns, whereas predation by $R$. rattus was much lower, and $<9 \%$ of their stomach contents was sooty tern and forest bird combined (Harper 2007). Norman (1970) experimentally determined that $R$. rattus does not kill Short-Tailed Shearwater (Puffinus tenuirostris) adults (ca. $425 \mathrm{~g}$ ) or 3-week-old juveniles in Tasmania but does remove and consume unattended eggs (46-47 mm length) and eats dead chicks. Chicks of Cory's Shearwater (Calonectris diomedea) that were 2-7 days old were commonly eaten by $R$. rattus, but chicks $\geq 3$ weeks old (equivalent to $2 / 3$ of the adult body mass) were never depredated (Igual et al. 2006). In addition, Igual et al. (2006) suggested that egg consumption by $R$. rattus occurs only when eggs are abandoned and likely broken by the adult; the large size of the Cory's Shearwater likely enables them to fend off $R$. rattus and protect their eggs. Zarzoso-Lacoste et al. (2011) offered different-sized bird eggs to captive wild $R$. rattus and found that only the small eggs $(14 \times 18 \mathrm{~mm})$ and not the $27 \times 35 \mathrm{~mm}$ or the $43 \times 56 \mathrm{~mm}$ eggs were consumed; however, when eggs were damaged by puncturing before being offered to $R$. rattus all egg sizes were consumed. Most nocturnal burrow-nesting species periodically leave their offspring unattended once the chick is only a few days old (Igual et al. 2006), which enables $R$. rattus the opportunity to access unattended eggs and chicks. On Midway Atoll $\left(28^{\circ} \mathrm{N}\right), 79 \%$ of Bonin Petrel (Pterodroma bypoleuca, 180-200 $\mathrm{g}$ adults) nests failed due to $R$. rattus predation of both abandoned eggs (size $38 \times 50 \mathrm{~mm}$ ) and those being incubated (Seto and Conant 1996). There were no adult Bonin Petrels consumed by $R$. rattus, and chicks were unlikely to suffer $R$. rattus predation (Seto and Conant 1996). In the tropics, the number of Galápagos Petrel (Pterodroma phaeopygia) chicks that fledged during two seasons increased $50 \%-100 \%$ following $R$. rattus control (Cruz and Cruz 1996).

Seabird characteristics that are associated with vulnerability to $R$. rattus appear to include burrowing and ground-nesting habits, small adult or chick body sizes (i.e., $<170 \mathrm{~g}$, which is within the average $R$. rattus body size 
range [Figure 2]), leaving eggs or young offspring unattended while foraging, and possibly small egg sizes (e.g., $\leq 50 \mathrm{~mm}$ longest length [Norman 1970, Amarasekare 1994, Seto and Conant 1996, Zarzoso-Lacoste et al. 2011]). Procellariiformes (e.g., petrels and shearwaters) may be particularly vulnerable to population-level impacts of $R$. rattus because they lay just one egg per year, have delayed maturity and long reproductive cycles, and often leave their offspring unattended to forage when the chick is only a few days old (Warham 1990, Seto and Conant 1996).

Native and nonnative rodent communities have also been altered by $R$. rattus invasion of Pacific islands. Harris (2009) conducted a review of the negative impacts of invasive rodents on native mammals and found that $R$. rattus has been implicated in at least six extinctions in the Pacific, including four from the Galápagos Islands (Nesoryzomys spp. rats), one from New Zealand (Mystacina robusta bat), and one from the Marías Islands in Mexico (Oryzomys nelsoni rat). Stokes et al. (2009) in Australia, and Harris and Macdonald (2007) in the Galápagos demonstrated that native rats (Rattus fuscipes and Nesoryzomys swarthi, respectively) suffered from interference competition with nonnative $R$. rattus. Furthermore, removal of $R$. rattus can result in population increases in coexisting nonnative rodents on Pacific islands, which has been observed with M. musculus in New Zealand (Ruscoe et al. 2011) and in the Galápagos (Harper and Cabrera 2010).

\section{Impact on Invertebrate Communities}

Population- and community-level impacts of $R$. rattus on invertebrates have rarely been studied, despite the importance of terrestrial invertebrates as detritivores, primary consumers, predators, prey, and pollinators. In a global review of the impacts of invasive rodents on island invertebrates, St. Clair (2011) highlighted cases in which invertebrate populations may have been driven to extinction by invasive $R$. rattus (e.g., flightless beetles Hadramphus stillborcarpae [Kuschel and Worthy 1996] and Dorcus belmsi [Ramsay 1978]) in southern New Zealand), but the majority of the recorded impacts have been population suppressions, which commonly involve beetles (Coleoptera), crickets/katydids (Orthoptera), and mollusks (especially large terrestrial snails). Additional arthropods that are commonly at risk from $R$. rattus include spiders (Araneae) and caterpillars (Lepidoptera) (Cole et al. 2000, Towns 2009, St. Clair 2011, Shiels et al. 2013). Towns (2009) suggested that the nocturnally active invertebrates are also particularly vulnerable to $R$. rattus predation. One generalization that was apparent from the St. Clair (2011) review was that largerbodied invertebrates, relative to smallerbodied ones, tend to be more vulnerable to local extinction and suppression by invasive $R$. rattus. Large beetles, weta (large flightless Orthoptera), giant land snails (Gastropoda), and large millipedes and centipedes (Arthropoda) are common prey items for introduced rodents in New Zealand islands, and giant stick insects (Phasmatodea) are preyed upon by $R$. rattus on Lord Howe Island (St. Clair 2011).

Terrestrial snails are at risk of predation by $R$. rattus in the Pacific (Clark 1980, St. Clair 2011). Snails that reside in trees, such as many of those native to Pacific islands, are often depredated by arboreal $R$. rattus; damaged shell remains from snail predation by $R$. rattus have closely correlated with declines in native tree snails in both the Hawaiian Islands (Hadfield et al. 1993, Hadfield and Saufler 2009) and the Ogasawara Islands (Chiba 2010a). Most sizes of snails are at risk of predation by R. rattus, including egg masses (Clark 1981) and 11-59 $\mathrm{mm}$ nonnative snails (Achatina fulica and Euglandina rosea [Meyer and Shiels 2009]). However, in the Ogasawara Islands, larger native snails $(>10 \mathrm{~mm})$ are at greater risk of $R$. rattus predation than smaller snails $(<10 \mathrm{~mm})$ (Chiba 2010a). In addition, native snails that occupy the ground are at risk of predation by $R$. rattus, particularly if they do not reside deeply within the leaf litter (Chiba $2010 a, b)$.

The general traits most useful for predicting invertebrate vulnerability to $R$. rattus appear to be large body size, nocturnal activity, flightless nature, and residence or activity at shallow leaf litter depths or exposed surfaces (Towns 2009, Chiba 2010a,b, St. Clair 2011). 
Future research on $R$. rattus-invertebrate interactions is clearly needed on islands outside temperate New Zealand and tropical Hawai' $i$, where the majority of our generalizations have originated (St. Clair 2011).

\section{Agricultural Impacts}

Rodents cause substantial losses to food production in all regions of the world (Witmer and Singleton 2010). In fact, Meerburg et al. (2008) estimated that 280 million malnourished people worldwide could benefit from pre- and postharvest rodent control. Pimentel et al. (2005) estimated that annual economic losses due to nonnative rats (including $R$. rattus) in the United States are approximately $\$ 19$ billion, and the majority of such losses result from consumption of grain and spoiling foods. Further estimates described in Pimentel et al. (2005) include a cost of $\$ 15 / \mathrm{yr}$ of grain or other material for each rat in the United States, and they estimated that roughly 250 million rats are in the United States. Of the 60 or more species in the genus Rattus, at least 14 are substantial agricultural pests, and $R$. rattus is likely to be the most damaging to agricultural crops globally (Aplin et al. 2003).

Most types of fruits and vegetables can be damaged by $R$. rattus in the field and in storage. Coconuts are well known as desired food items for rats in tropical countries, and in Tonga $R$. rattus was the sole cause of the $20 \%$ loss of the coconut crop during one study (Twibell 1973). Rattus rattus has pronounced negative effects on rice (Oryza sativa), particularly in the Philippines and Southeast Asia (Fall and Sumangil 1980, Aplin et al. 2003, Miller et al. 2008). The macadamia nut industry in both Australia and Hawai'i suffers $5 \%-30 \%$ crop losses from nut consumption by $R$. rattus (Tobin et al. 1990, 1994, 1996, Elmouttie and Wilson 2005). Rattus rattus consumes most macadamia nuts by foraging in the canopy (Tobin et al. 1996), yet in the rows that are adjacent to crop edges $R$. rattus removes numbers of nuts that drop to the ground equivalent to those that are consumed in the canopy (Elmouttie and Wilson 2005). Seeds, fruits, and vegetables that are stored in bags and boxes are also damaged by $R$. rattus, including cauliflower (Brassica oleracea), sweet orange (Citrus sinenis), mango (Mangifera indica), grape (Vitis vinifera), and apple (Malus pumilla) (Ahmad et al. 1993).

Introduced rats have been a major threat to agriculture in Hawai'i for at least the past 170 yr (Tobin et al. 1990). In 1990, it was estimated that annual revenues from sugarcane (Saccharum spp.) alone in Hawai'i exceeded \$350 million, with annual losses from rat destruction of sugarcane averaging about $11 \%$ (Tobin et al. 1990); however, it was not uncommon to lose about $30 \%$ of a sugarcane crop to invasive rodents (Hood et al. 1971). The timing of crop damage was critical for planning control strategies for rat impacts, and damage to sugarcane became appreciable at 14 months and peaked at 19-21 months. The edges of the sugarcane fields suffered the most damage, despite trapping showing uniform rat abundance across the fields (Hood et al. 1971). Rattus rattus damages tropical fruit (e.g., rambutans [Nephelium lappaceum], bananas [Musa spp.]) and seed crops (e.g., corn [Zea mays], soybeans [Glycine max] [Pitt et al. 2011a]), and such damage may be more common in modern Hawai' $i$ than in the past because of the increased tropical fruit and seed crop acreage following the demise of the sugarcane industry (R.T.S., unpubl. data). Much increased labor and costs due to necessary $R$. rattus control strategies are required to protect crops on Pacific islands, including control efforts in crop fields, adjoining noncrop areas, and in storage and transportation units (Hood et al. 1971, Ahmad et al. 1993, Elmouttie and Wilson 2005).

\section{Human Health Impacts}

Meerburg et al. (2009) reviewed the large number of pathogens that rodents can directly or indirectly transmit to humans. Rattus rattus is a carrier of a number of diseases that are serious threats to humans. Such diseases are typically transferred to humans via urine and droppings or through hosts that interact with both $R$. rattus and humans. We describe some of the most problematic human-threatening diseases that are carried by $R$. rattus, including those resulting from bacteria (e.g., bubonic 
plague, leptospirosis) and nematodes (rat lung worm disease); we then describe some infections that are much less threatening to humans but can be relatively common within $R$. rattus in the Pacific.

More than 200 species of mammals may host fleas that harbor the bubonic plague (Yersinia pestis). Although most mammalian species can suffer from the impacts of $Y$. pestis, both $R$. rattus and $R$. norvegicus show moderate levels of resistance (Aplin et al. 2003), and $R$. rattus was the main host of this disease that historically affected humans (Alderton 1996). By the 1800 s, the bubonic plague, or Black Death, had wiped out more than 25 million people in Europe and an additional estimated 50 million in Asia and Africa; by the early 1900s the plague had reached many Pacific islands and popular ports (Twigg 1978, Alderton 1996). In an effort to arrest the plague outbreak in Hawai'i, the Chinatown district of Honolulu was burned and strict quarantine measures were practiced (Tomich 1986). The plague in Hawai'i caused at least 370 human fatalities, and the last reported case of human infection in Hawai'i occurred in 1949 (Sugihara 2002). Rattus rattus was also the likely source of the plague outbreak in Australia in the early 1900 s, where about 180 people died, mainly in the densely populated cities of Sydney, Brisbane, and Melbourne (Curson and McKracken 1989). Improved sanitation, mechanized agriculture, and natural and/or human-mediated control of the reservoir (rat) and vector (flea) populations have likely reduced outbreaks of the plague (Tomich et al. 1984). However, even today bubonic plague is a potential killer; antibiotics can help overcome the bacterium and a vaccine is available, yet the infection can spread around the world at frightening rates due to our modern means of transportation (Alderton 1996).

In addition to the fleas that harbor Yersinia pestis, ticks and mites carried by $R$. rattus can harbor bacteria that can infect humans. In eastern Australia and Tasmania some of the bacterial infections that have resulted from $R$. rattus include Rickettsia spp., which causes tick typhus or spotted fever (Singleton et al. 2003); Orientia tsutsugamushi, or scrub typhus; and Coxiella burnetii, which may cause Q fever
(Banks and Hughes 2012). Symptoms of these bacterial infections in humans can include headaches and muscle aches, nausea, vomiting, mental confusion, rash, pneumonia, encephalitis, and heart failure (Banks and Hughes 2012). Streptobacillus moniliformis, or rat-bite fever or Haverhill fever, can be transmitted to humans through rat bites or scratches, as well as via contact with infected rat urine or feces. Symptoms from human contraction of the bacteria generally include fever and arthritis (Singleton et al. 2003). Salmonella spp. are also carried by $R$. rattus, and although they do not appear to have any ill effects on $R$. rattus, they can be transferred to humans and livestock (Lapuz et al. 2008).

Leptospirosis is a worldwide zoonotic infection that occurs from Leptospira bacteria transferred to humans through exposure to water or soil contaminated with urine or feces from infected mammalian hosts, such as $R$. rattus (Wong et al. 2012). The Leptospira bacteria become concentrated in the rats' kidneys and are passed out of the rat via their urine. These bacteria survive well in water and can enter humans through any damaged skin, mucous membranes, or the conjunctiva of the eye. Infection by Leptospira icterohaemorrhagiae, which results in the human illness called Weil's disease, is the most serious form of human infection. Dogs are also at risk from a strain called L. canicola, and they may spread this to their owners, but a vaccine for dogs has led to dramatic declines in the incidence of this disease (Alderton 1996). In Hawai' $i$, approximately $13 \%$ of $R$. rattus are carriers of Leptospira spp. (Wong et al. 2012).

Rattus rattus (as well as $R$. exulans and $R$. norvegicus) are definitive hosts of the nematode Angiostrongylus cantonensis, or rat lung worm (Wang et al. 2008). Human infections of rat lung worm can result in the main clinical manifestation of eosinophilic meningitis, and human infection generally arises from consumption of the intermediate host (typically slugs and snails). Thus, to complete its life cycle, the nematode needs both the rat host and a gastropod intermediate host. Humans, birds, and other mammal hosts can suffer from meningitis symptoms and death from $A$. cantonensis infection (Prociv et al. 2000). Since 
1945 , more than 2,800 human cases have been reported in over 30 countries; symptoms of the infection range from headaches and neck stiffness to numbness, coma, and death (Wang et al. 2008). Screening of $R$. rattus for $A$. cantonensis infection during the last $70 \mathrm{yr}$ in the $\mathrm{Pa}$ cific has revealed infection rates ranging from $3 \%$ (Taiwan) to 20\%-30\% (Australia, Fiji, Japan) to 100\% (Thailand) (Wang et al. 2008).

Calodium bepatica is another nematode that is found in $R$. rattus, and it can infect humans through ingestion of the $C$. bepatica eggs. Human infection is rare $(37$ cases reported globally) despite $R$. rattus infection rates reaching 79\% in some Pacific regions (Waddell 1969, Banks and Hughes 2012). Rattus rattus may also act as reservoirs for the protozoan Toxoplasma gondii, which requires cats to complete its life cycle. Humans can obtain Toxoplasma oocytes through contact with cat feces. Some species of Cryptosporidium are a threat to human health, particularly in urban areas, and $R$. rattus is known to be a carrier of the protozoa (Banks and Hughes 2012).

There are several types of parasites that infect $R$. rattus that are much less likely to be transferred to, or infect, humans. Rattus rattus can be carriers of a number of blood parasites, such as Trypanosoma lewisi and Grabamella sp., which occurred in $10 \%-25 \%$ of $R$. rattus examined in Hawai'i (Kartman 1954). Also in Hawai' $i$, ear mites (Notoedres muris) that cause ear lesions can infect $26 \%$ of the $R$. rattus population in some forests but other populations suffer very little $(<2 \%)$ infection (Shiels 2010). Intestinal worms (helminths), likely the nematode Mastophorus muris, are common in wild $R$. rattus on many Pacific islands (Fall et al. 1971, Sugihara 1997, Shiels 2010), and the majority of the $R$. rattus captured were parasitized by this worm on Palmyra Atoll (Lafferty et al. 2010) and on Rangitoto Island, New Zealand (Miller and Miller 1995). Because the nematodes M. muris and Physoloptera getula have obligate life cycles involving arthropods as intermediate hosts, $R$. rattus is likely infected directly by eating its arthropod prey (Miller and Miller 1995). In addition, parasitic mites cause mange in $R$. rattus in both the tropical North Pacific (Shiels 2010) and South Pacific (Caut et al. 2008a).

\section{Regulatory Aspects}

On all islands in the Pacific $R$. rattus is generally consider a pest, and therefore importation of $R$. rattus (accidentally or intentionally) is unwanted. However, $R$. rattus inhabits most island groups in the Pacific, so movement of rats probably has little impact on established populations in most situations beyond the potential for rats to spread diseases. One notable exception is islands and areas that have never had rats or have eradicated rats and maintained biosecurity measures to prevent reestablishment. Formal regulations against $R$. rattus transport and establishment are lacking for most Pacific islands (Moors et al. 1992). However, the International Health Regulations of 1969 states that all ships containing overseas goods must have a certificate stating that their vessel is maintained as rodent-free or is "periodically deratted"; certificates are issued by the health authority at approved ports and they are valid for 6 months (World Health Organization 1995). It is unlikely that such certification prevents rodent movements among landmasses, although some reductions may result. Aircraft and ships are vectors for repeated introductions of stowaway species like $R$. rattus because of routine routes traveled and regularity of transport schedules. Ship personnel control rodents aboard aircraft and ships, and some countries require routine inspection of ships in their ports and also require biosecurity measures for ships docking to reduce the risk of importing rodents. Such ship-to-shore measures may include rat guards on mooring lines, separation of gangways and cargo nets from piers at night and when not in active use, and maintaining rodent control with rodenticide baiting and trapping on ships and $200 \mathrm{~m}$ distant from the wharf (Moors et al. 1992). On islands where rats have been eradicated, additional biosecurity measures are typically required (Moors et al. 1992, Russell et al 2008).

\section{Beneficial Aspects}

Despite its remarkable adaptability, $R$. rattus is highly destructive and is generally unpopular with people. There are few beneficial im- 
pacts of $R$. rattus, and its destructive impacts on island ecosystems seem to far outweigh any positive ones. One potentially positive impact of $R$. rattus is its possible functional replacement of extinct island fauna, such as taking a role in seed dispersal (Abe 2007, Shiels and Drake 2011) or possibly pollination (Cox 1983, Innes 2001). Additional benefits related to $R$. rattus may include personal financial gain through rat catching and control, as well as a source of food and entertainment (at least historically).

Many species of rodents are popular cuisine in many parts of the world, and rats are often hunted in Africa and Asia as a readily available source of protein. Early Polynesian voyagers in the Pacific may have purposefully kept $R$. exulans on their ships as an emergency food source, and $R$. exulans was trapped and eaten as an esteemed food source during Māori ceremonial feasts in New Zealand (Atkinson and Towns 2005). The degree to which $R$. rattus was consumed on islands or historical voyages in the Pacific is unknown, yet news reports from the 1940s indicated that men survived in part by eating rats on Wake Atoll (Fisher and Baldwin 1946), and at least one entry from Captain Cook's journal noted that a midshipman on the Resolution cleaned, roasted, and consumed part of a rat that the ship cat had caught (Beaglehole 1969).

Rat capture and removal have been a major income source in many countries. During the Victorian Era in Britain (1837-1901) when rats were particularly widespread pests, money was to be gained by using live rats for entertainment purposes. In public houses, rat pits were often established where pet dogs were encouraged by their owners and spectators to kill as many rats as possible within a set period. One dog, a terrier, killed a record 500 rats in just $5.5 \mathrm{~min}$ (Alderton 1996). Because of the great supply of rats needed for this type of entertainment, many rat-catchers (as many as 20 per public house) were employed for this purpose. Rats from sewers were avoided because they would most likely cause the dogs to become ill (Alderton 1996); therefore some of the rats used in rat pits would probably have been $R$. rattus. Today, control and extermina- tion of $R$. rattus can result in relatively large financial gains in some urban and natural settings (e.g., Scofield et al. 2011).

In the early and mid-1900s rats became popular pets, especially with young women, who often kept them in squirrel cages. Breeders would develop strains with new colors and patterns. Although most modern pet rats are descendants of $R$. norvegicus, there were several color variants of $R$. rattus bred during the early 1920s; the most unusual of these was a bizarre greenish-colored strain (Alderton 1996).

GEOGRAPHIC DISTRIBUTION IN THE PACIFIC REGION

Rattus rattus is distributed globally outside the polar regions, with perhaps the highest latitude of occurrence at $63^{\circ} \mathrm{N}$ in Sweden (J. E. Brooks and F. P. Rowe, 1987, unpubl. report on commensal rodent control, WHO/VBC/ 87.949 [cited in Innes 2005a]). In the Pacific, $R$. rattus extends from the Queen Charlotte Islands, British Columbia $\left(53^{\circ} \mathrm{N}\right)$ (Golumbia 2000) to subantarctic Macquarie Island $\left(55^{\circ}\right.$ S) (Copson 1986). Of the 30 archipelagos in the Pacific that were identified by Carvajal and Adler (2005), which included those between $25^{\circ} \mathrm{N}$ and $25^{\circ} \mathrm{S}$ and from $120^{\circ} \mathrm{W}$ westward through the Bismarck and Palau archipelagos, $R$. rattus occurs on at least 27 of the archipelagos (A.B.S., J. Russell, and W.C.P., unpubl. data); those that $R$. rattus are potentially absent from include Rotuma, Pitcairns, and Tokelau, which may harbor $R$. exulans or other invasive rodents (A.B.S., J. Russell, and W.C.P., unpubl. data).

Island colonization by $R$. rattus in the $\mathrm{Pa}$ cific varied greatly during the past $300 \mathrm{yr}$ (see Atkinson [1985] for a review). From Britain it was spread throughout the world along shipping routes and probably reached the Pacific by the 1850s (Atkinson 1985). Of course many islands in the Pacific were first discovered by Europeans before 1850 (e.g., the Galápagos in the late seventeenth century and most other Pacific islands in the late eighteenth century). However, Atkinson (1985) pointed out that the European ships that first landed on most of the Pacific islands would have been 
carrying $R$. norvegicus stowaways rather than $R$. rattus; the reasoning behind this is that $R$. rattus was the only nonnative rat in Britain until $R$. norvegicus was introduced about 1716 , and it competitively displaced $R$. rattus from the wharfs and thereby the ships traveling to the Pacific. Records indicate that $R$. rattus suddenly reappeared on European ships during the 1850 s, which is a change that still remains unexplained (Atkinson 1985). Nevertheless, the first $R$. rattus that arrived on most Pacific islands are believed to have arrived from this British stock (Atkinson 1985).

Once $R$. rattus was established in the $\mathrm{Pa}$ cific, islands that are relatively close to one another (i.e., 300-750 m) could be colonized by swimming rats (Innes 2005a). Russell and Clout (2004) determined some of the predictive factors that influence whether or not New Zealand islands are colonized by $R$. rattus. The factors that positively influence the presence of $R$. rattus on New Zealand islands included island area, presence of a landing structure (wharf), and whether or not the island was inhabited by humans. Factors shown to negatively influence the presence of $R$. rattus included elevation, distance to nearest island, and the number of rock types. Finally, the factors that had no significant effect on $R$. rattus presence included number of seabirds, number of nonnative land birds, number of introduced rodents, number of introduced mammals, and the number of abandoned settlements (Russell and Clout 2004).

\section{НAB IT AT}

\section{Climate Requirements, Limitations, and Ecosystems Invaded}

Rattus rattus is widely distributed throughout tropical, alpine, and subpolar climates, and the species has invaded ecosystems from shorelines to mountain peaks. The only places where $R$. rattus is not found in the Pacific seem to be within the highest latitudes (those $>55^{\circ}$ ) (A.B.S., J. Russell, and W.C.P., unpubl. data) and the highest elevations (in most cases $>3,000 \mathrm{~m}$ ) (Amarasekare 1994). On Hawai' $\mathrm{i}$ Island, Amarasekare (1994) did not find $R$. rattus above $2,837 \mathrm{~m}$, which is approximately the vegetation boundary in the alpine desert ecosystem; $R$. rattus generally occurs in low abundances near those upper elevations (less than one individual/ha at $2,100-2,500 \mathrm{~m}$ [Amarasekare 1993]; 0.2 individuals/trapnight at 1,785-2,600 m [Banko et al. 2002]). Poa foliosa tussock grassland is the principal habitat for $R$. rattus on Macquarie Island (55 $S)$, probably because it provides year-round food, shelter, and a slightly warmer microhabitat than outside the tussock canopy (Pye et al. 1999). Black rats have not been found in the windswept uplands of Macquarie Island, where lichens and cushion-forming plants dominate, including Azorella and bryophytes (Pye et al. 1999). The upper latitudes and elevations may reflect the boundaries of cool temperatures that $R$. rattus can withstand, yet food scarcity and lower ambient oxygen levels may also be factors contributing to distributional limitations in such cool environments. Rattus rattus does not seem to be limited by an upper temperature level, or at least this has not been investigated. Thus, $R$. rattus is abundant and spans most terrestrial communities, from arid lowland and montane ecosystems (Tamarin and Malecha 1971, Clark 1981, Amarasekare 1994, Harris and Macdonald 2007, Chimera and Drake 2011) to lowland and montane rain forests (Daniel 1973, Sugihara 1997, Lindsey et al. 1999, Wegmann 2009). Even in highly disturbed environments, such as Eniwetok Atoll, which suffered numerous nuclear explosions, $R$. rattus survived in densities of approximately 20 individuals/ha $10 \mathrm{yr}$ after the last nuclear test (Fall et al. 1971).

Rattus rattus survives on islands that do not contain bodies of fresh water (e.g., many atolls, dry forests). Unlike $M$. musculus, $R$. rattus appears incapable of concentrating its urine, and $R$. rattus was unaccepting of seawater when offered it (Norman and Baudinette 1969). Therefore, much or all of black rat water requirements for survival probably comes from foods consumed (e.g., fleshy fruits, vegetative material), yet dew and rainfall are other sources of water to fill survival requirements for R. rattus (Alderton 1996). 
Habitat Resource Requirements and Limitations

Rattus rattus commonly utilizes belowground, ground, and aboveground habitats. Relative to other invasive Rattus spp. and Mus musculus, $R$. rattus uses a much greater proportion of the arboreal habitat (Lindsey et al. 1999, Shiels 2010), and $R$. rattus prefers forests over open, heath, and scrub macrohabitats in Australia (Cox et al. 2000). Preference of $R$. rattus for arboreal habitats is further supported by its numeric dominance over other coexisting rodents in most insular forests in the Pacific (Tamarin and Malecha 1971, Daniel 1973, Clark 1981, Sugihara 1997, Yabe et al. 2010). However, $R$. rattus does not require forest or substantial vertical structure, as evidenced by its high abundance in savannahs (Clark 1981) and on atolls with low scrub vegetation (Fall et al. 1971).

Unlike its high abundance in most insular forests, $R$. rattus is not always the dominant rodent species in agricultural settings. Tobin and Sugihara (1992) examined the relative abundances of three species of sympatric rats in sugarcane fields in Hawai'i. They found that either $R$. norvegicus or $R$. exulans was the most numerous within any given field and that $R$. rattus was captured mainly near field edges where trees were present. During 11,200 trap-nights, Tobin and Sugihara (1992) captured $526 R$. norvegicus, $335 R$. exulans, and $139 R$. rattus in four sugarcane plantations that regularly experienced pronounced rat damage. The importance of arboreal habitat availability for $R$. rattus is evident historically in the United Kingdom, where $R$. rattus was not able to coexist with $R$. norvegicus because of interference competition ( $R$. norvegicus is larger than $R$. rattus) coupled with the presence of an arboreal rodent (the native red squirrel Sciurus vulgaris) that already occupied the arboreal niche (King et al. 2011a).

Den sites are important habitat features for black rats because roughly half of their lives are spent in them. Common den sites for $R$. rattus include cavities in trees or rocks, beneath woodpiles or dense vegetation cover, fern and stick-lined arboreal nests, and in burrows belowground (Lindsey et al. 1999, Ruth- erford et al. 2009, Shiels 2010). In Hawaiian montane rain forests, Lindsey et al. (1999) used radio tracking to determine that $R$. rattus $(n=9)$ nested in trees or treeferns, whereas Shiels (2010) found that $R$. rattus $(n=24)$ used a mixture of aboreal and belowground den sites and nearly half of the monitored individuals switched their den site uses between tree cavities and burrows. Larger trees (in height and girth) were the most common trees in which $R$. rattus denned in Hawaiian forests, and these included nonnative Aleurites moluccana and Grevillea robusta, and native Acacia koa and Metrosideros polymorpha (Lindsey et al. 1999, Shiels 2010). In New Zealand forest, Hooker and Innes (1995) found that all of the $R$. rattus radio-collared in their study had dens in trees and that the den sites were too high $(>2 \mathrm{~m})$ to pinpoint from the ground. Unlike other studies where $R$. rattus was typically found denning only in trees, all of the 14 $R$. rattus followed on a 797 ha offshore island in southern New Zealand (Taukihepa) had dens belowground despite the presence of a short-statured forest; many of the dens were in seabird burrows, beneath logs and branches, and in fern cover (Rutherford et al. 2009). On Macquarie Island, where trees are absent, Pye et al. (1999) documented extensive tunneling that connected entrances to $R$. rattus den sites in coastal tussock habitat.

Habitat partitioning, which can reduce competition, has been previously observed for $R$. rattus when it is sympatric with other introduced rodents (Shiels 2010). Experimental evidence of habitat partitioning between $R$. rattus and $R$. exulans was demonstrated by Strecker and Jackson (1962), where several rats of each species were confined in $3 \times 3 \mathrm{~m}$ enclosures for 14 days and then examined for signs of conflict and weight loss. The authors concluded that if food and available microsites were present, these rats could coexist in a confined space. However, when smaller cages limited space and microhabitats to a greater extent or arrival times of different rat species into the cage were altered, then there was strong evidence of interference competition that resulted in fighting and high death rates (Barnett 1964, Norman 1970). In Australia, 
Stokes et al. (2012) experimentally determined that the resident species ( $R$. rattus or native $R$. fuscipes) were dominant in their behavior relative to intruders $88 \%$ of the time, irrespective of the rodent species that was the intruder.

\section{PHYSIOLOGY AND BEHAVIOR}

The physiological and behavioral adaptations of $R$. rattus have likely aided in its successful establishment in Pacific island ecosystems. Rattus rattus has a relatively high metabolic rate and keen sense of smell. Black rats are agile, move beneath vegetation cover rather than in exposed areas, use aboveground habitat (trees) more than other introduced rodent species, and typically move food items upon collection but generally do not store (cache or hoard) them (see section on Impact on Plant Communities under Economic Importance and Environmental Impacts). An important point for rat control and eradication programs is that rats typically suffer from "neophobia," which is fear of new objects; it occurs when there is a change in an otherwise familiar situation (Barnett 1963, Clapperton 2006).

Rodents have large surface areas relative to their volume, which results in greater heat losses from their bodies when compared with larger mammals. Thus, to maintain their body temperatures, rodents have high metabolic rates. Some rodents must find and eat up to $70 \%$ of their body weight each day to support their metabolic requirements (Alderton 1996). Captive $R$. rattus consumed $14-18 \mathrm{~g}$ of pellet bait and a slice of apple each day (Clapperton 2006). Rattus rattus does not hibernate, and in winter and early spring months on Macquarie Island $\left(55^{\circ} \mathrm{S}\right)$ black rats retrieved seeds from established surface caches to sustain themselves until natural seedling recruitment commenced in the spring (Shaw et al. 2005).

Rattus rattus has a keen sense of smell that is readily used during foraging and communication with other individuals (Mallick 1992, Innes 2005a,b). Mallick (1992) found that both sexes of $R$. rattus mark substrates with urine at equal rates, and that urine marking probably contains olfactory cues that are used in intraspecific communication. Scent markings from other animals do not always affect $R$. rattus behavior. Stokes et al. (2012) experimentally determined that $R$. rattus does not appear to respond to traps scented with a competing rat species (Rattus fuscipes) in Australia. However, scents of predators, such as mongooses, were avoided by $R$. rattus (Tobin et al. 1995). Rattus rattus also follows scents to revisit locations and to find prey; rats are constantly, or nearly so, sniffing the air and are well attuned to foreign sounds (Innes 2005a). In New Zealand, $R$. rattus located some bird nests before eggs were laid, then returned regularly to the nests during the egg-laying period, and finally depredated several eggs (Innes 2001). Exposed and concealed nests were equally vulnerable to predation, suggesting that rats do not readily rely on visual cues to locate nests (Innes 2001). Selvaraj and Archunan (2006) determined that male $R$. rattus scent provided by both cheek cells and urine increased the acceptance of poison bait by female $R$. rattus.

Black rats are agile, good climbers, excellent jumpers, and adept swimmers (Meehan 1984, Innes 2005a, Foster et al. 2011, King et al. 2011a). They have been documented jumping higher than $150 \mathrm{~cm}$ (Meehan 1984), and all 20 adults of various body sizes (range, 87-173 g) that were tested in Hawai'i were able to jump at least $40 \mathrm{~cm}$ high (Pitt et al. $2011 d$ ). When $R$. rattus was compared with $R$. norvegicus in New Zealand pen trials, Foster et al. (2011) determined that $R$. rattus was faster moving and more agile, more easily overcame obstacles, was less dependent on footholds, was less likely to fall, and could more easily reach unsupported ends of small branches. Rattus rattus can also fit through small holes, and all 16 adults tested of various body sizes (range, 85-162 g) were able to pass through $35 \mathrm{~mm}$ diameter holes to access food (Pitt et al. 2011d). Black rats have been known to swim 300-750 m to colonize adjacent islands (Innes 2005a).

Rodents are often in areas of relatively high vegetation cover presumably to limit their exposure to predators (Alderton 1996, Cox et al. 2000, Atkinson and Towns 2005). Using spool-and-line tracking in the Wai'anae 
Mountains on O'ahu, $R$. rattus was observed under vegetation ground cover an average of $88 \%$ of the monitoring time when rats were out of their dens and active on the ground and aboveground (Shiels 2010). In eastern Australia, Cox et al. (2000) found that $R$. rattus preferred densely vegetated understories and showed a significant attraction to habitats with increased leaf litter when their population density was relatively high. The directions of rat movements are often unpredictable because their exploratory behavior is influenced by both scents and other features that are encountered in the environment (Barnett 1963). Often a $R$. rattus individual doubles back over its same pathway by circling or moving a few decimeters in one direction, then returns to a point that it had already traveled before it quickly changes paths and explores a new direction (Key and Woods 1996 , Shiels 2010). The average height $R$. rattus was observed active aboveground was 2.8 $\mathrm{m}$ (Shiels 2010), yet black rats can spend an average of $30 \%-90 \%$ of their night activity on the ground (Dowding and Murphy 1994, Hooker and Innes 1995, Lindsey et al. 1999, Shiels 2010).

Rattus rattus typically leaves its den just after sunset and returns just before sunrise (Hooker and Innes 1995, Shiels 2010); however, some rats return to their den partway through the night and then resume foraging (Dowding and Murphy 1994). One female rat in the study by Shiels (2010) left her den site at sundown (three nights) or $17 \mathrm{~min}$ before sundown (one night). In macadamia nut orchards, black rats left their dens 1-2 hr after sunset and returned 1-2 hr before sunrise (Tobin et al. 1996). Rattus rattus is rarely active during the day unless densities are high (>50 individuals/ha) and predators are absent, such as previously documented on Palmyra Atoll (Wegmann 2009). As evidence of their pronounced social behavior, multiple $R$. rattus individuals den together, and they do not typically occupy just one den site during the period that they are monitored (Dowding and Murphy 1994, Lindsey et al. 1999, Rutherford et al. 2009). Over a range of monitoring periods (1-20 weeks), $R$. rattus changed den sites to different trees one to three times at
Hakalau Forest on Hawai'i Island (Lindsey et al. 1999), three to five times in the Rotoehu Forest, North Island, New Zealand (Hooker and Innes 1995), two to nine times in Puketi Forest, North Island, New Zealand (Dowding and Murphy 1994), and one to 11 times in Kahanahāiki Forest on O'ahu (Shiels 2010).

Determining $R$. rattus home ranges helps elucidate rat distribution and habitat preference and assists with rat control strategies such as trap and bait-station spacing (Howald et al. 2007). Home ranges of $R$. rattus in two montane mesic forests on $\mathrm{O}^{\prime}$ ahu (1.5-9.1 ha [Shiels 2010]) were nearly as variable as those in a South Island, New Zealand, beech forest (0.3-11.4 ha [Pryde et al. 2005]). Other New Zealand studies in North Island forests found that $R$. rattus home ranges were much smaller (e.g., $0.3-1.8$ ha in a study by Dowding and Murphy [1994], and 0.3-2.2 ha in Hooker and Innes [1995]). When $55 R$. rattus were monitored in Hawaiian macadamia nut orchards, average home-range sizes were 0.2 ha (Tobin et al. 1996). Lindsey et al. (1999) determined that $R$. rattus home range averaged 4.2 ha for three males and was 1.8 ha for one female in montane wet forest on Hawai'i Island. Male $R$. rattus often have larger home ranges than females (two times larger in Whisson et al. [2007]; three times larger in Hooker and Innes [1995]; more than nine times larger in Pryde et al. [2005]), yet average home range sizes do not always differ between sexes (Dowding and Murphy 1994, Shiels 2010). Movements between captures can range from 18 to $174 \mathrm{~m}$ (Clapperton 2006), and in Hawaiian mesic forest the maximum distances that $R$. rattus $(n=12)$ was recorded from den sites during nighttime foraging averaged $45 \mathrm{~m}$ (Shiels 2010).

\section{REPRODUCTION AND POPULATION DYNAMICS}

Owing to the prolific nature of rodents, rapid, exponential increases in populations are common (Krebs et al. 1973), especially on islands (Martin et al. 2000). The female $R$. rattus reproductive biology includes an estrous cycle of 4-6 days, a 20- to 22-day gestation period, and 21-29 days to complete weaning (Innes 
$2005 a$ ). According to laboratory studies, $R$. rattus reaches sexual maturity at 2-4 months (Watts and Aslin 1981). Rattus rattus is capable of having litters every 32 days (range, 27-38 [Innes 2005a]), and four to six litters per year is common (Tobin et al. 1994, Efford et al. 2006). Each litter typically averages 3-6.5 individuals (Tobin et al. 1994), yet in laboratory trials the litter size ranges from three to 10 and averages five to eight (Innes 2005a). On a small New Zealand island, Moller and Craig (1987) found that female $R$. rattus produced 19-21 young per year (in three litters). Rattus rattus is not monogamous, and multiple paternity in a single litter has been demonstrated for wild $R$. rattus (Miller et al. 2010).

Rattus rattus density can vary greatly among sites and islands in the Pacific. For example, density estimates for $R$. rattus in Hawai'i include 0.7 individuals/ha in high-elevation shrubland (Amarasekare 1994), 3.6 individuals/ha in lowland wet forest (Beard and Pitt 2006), 7.1 rats/ha in montane mesic forest (Shiels 2010), and 8-15 individuals/ha in lowland dry forest (Tamarin and Malecha 1971). In New Zealand, $R$. rattus density estimates in forests ranged from 0.5 to 6.8 rats/ha (Dowding and Murphy 1994, Hooker and Innes 1995, Brown et al. 1996, Innes et al. 2010). Rattus rattus populations on Pacific islands have densities comparable with those within its native range in India, which includes 14.5 individuals/ha in tropical forest (elevation 340-2,400 m) (Chandrasekar-Rao and Sunquist 1996) and 2-36 individuals/ha in tropical forest and savannah (elevation 1,800-2,500 m) (Shanker and Sukumar 1999); however, density comparisons should be interpreted cautiously because of the wide range of factors that are dissimilar among rattrapping studies (e.g., habitat, trapping regime, rodent species composition, abundance and density calculation).

Estimates of $R$. rattus abundances based on the number of individuals per 100 trap-nights were 8-17 in montane wet forest on Maui (Sugihara 1997), 8-14 in montane mesic forest on O'ahu (Shiels 2010), and 11-25 in montane wet forest on Hawai'i Island (Lindsey et al. 1999). In a study on South Island,
New Zealand, Alterio et al. (1999) found that abundances of $R$. rattus ranged from 1.8 to 5.6 individuals/100 trap-nights. In a 5-yr study of $R$. rattus in North Island, New Zealand, Innes et al. (2001) found that abundances were 1-20 individuals/100 trap-nights (mean ca. 8-10). Other studies of $R$. rattus from North Island, New Zealand, found that abundances ranged from 5 to 35 individuals/100 trap-nights (Dowding and Murphy 1994, Wilson et al. 2007).

Determining the causes of pronounced population fluctuations and density differences among sites has been one of the greatest challenges in animal ecology (Krebs et al. 1973). Availability of resources, rainfall, predator abundance, and disease are all factors that can potentially influence population dynamics of $R$. rattus. For example, dramatic seasonal increases in rat and mouse populations in New Zealand were explained by several correlated factors including litter arthropods, beech (Northofagus truncata) flowers (Fitzgerald et al. 1996), fruit and seed availability (Alley et al. 2001), and predator populations (Efford et al. 2006). Studies in New Zealand have suggested that stoats and cats are key predators that may partly regulate $R$. rattus populations (Innes et al. 2001, Blackwell et al. 2003, Efford et al. 2006), and cats and mongooses are rodent predators in Hawai' $i$ that may influence $R$. rattus populations (Tamarin and Malecha 1971, Shiels 2010). Food availability may be an important factor influencing rodent reproduction and abundance (Blackwell et al. 2003). Juvenile $R$. rattus abundance in mesic montane forests on $\mathrm{O}^{\prime}$ ahu was highest in June-December, which coincides with the seasonal timing of the heaviest fruiting and seed fall of Psidium cattleianum (June-October) and may influence the reproductive timing and juvenile abundance of $R$. rattus (Shiels 2010). Psidium cattleianum is a common tree in most wet and mesic forests in Hawai' $i$ that produces high seed rain, and it is a highly desired food item for $R$. rattus (Shiels and Drake 2011, Shiels et al. 2013). Late summer and autumn are also seasons when juvenile $R$. rattus abundance is highest in lowland dry forest on $\mathrm{O}^{\prime}$ ahu (Tamarin and Malecha 1971) and in New Zealand (Innes et al. 2001). 
There are typically more male rats in a given population than females (Sugihara 1997, Innes 2005a,b), and peak $R$. rattus densities (all age classes and both sexes) occurred from October through January (autumn and winter) in montane and coastal forest on $\mathrm{O}^{\prime} \mathrm{ahu}$ (Tamarin and Malecha 1971, Shiels 2010). Similarly, in a 27 yr snap-trap study in Orongorongo Valley, New Zealand, autumn and winter were also the peak seasons for $R$. rattus density (Efford et al. 2006).

Maximum survival of $R$. rattus is about $2 \mathrm{yr}$ in the wild, but mean survival is usually $1 \mathrm{yr}$ or less (Weinbren et al. 1970, Shiels 2010). In the laboratory, however, mean longevity for $R$. rattus is much longer, and Bentley and Taylor (1965) recorded average life spans of $3.9 \mathrm{yr}$ for males and $3.4 \mathrm{yr}$ for females. Annual disappearance rates for $R$. rattus during a 2 yr live-trapping study exceeded $90 \%$ for both sexes in the Orongorongo Valley, New Zealand. Few rats survived more than a year in the field, and the maximum longevity recorded was 11 months for males and 17 months for females (Daniel 1972). In Hawaiian montane forest, $R$. rattus individuals that were recaptured at the end of a $2 \mathrm{yr}$ study had lived $10.9 \pm 1.4$ months (mean $\pm \mathrm{SE}$ ), and four of 18 individuals were alive at 19 months of age (Shiels 2010).

\section{NATURAL ENEMIES}

Cats (Felis catus) and owls (particularly the Barn Owl Tyto alba) are the most ubiquitous predators of $R$. rattus on most Pacific islands, and these predators are generally nocturnally active like $R$. rattus. Other raptors, primarily hawks and eagles, also consume $R$. rattus on Pacific islands. Mongooses (Herpestes auropunctatus) consume $R$. rattus on several Pacific islands (Hays and Conant 2007). In New Zealand, Mustela spp. (stoats, weasels, and ferrets) are predators of $R$. rattus. Several species of civets (Viverridae), which are nocturnal mammals, are predators of $R$. rattus in the Philippines (Rickart et al. 1993). Monitor lizards (Varanus indicus) and the brown tree snake (Boiga irregularis) are predators of $R$. rattus in the Mariana Islands (Wiewel et al. 2009), and $R$. rattus has been found in the gut of several brown tree snakes in Guam (R.T.S., unpubl. data). In Tasmania, Tasmanian devils (Sarcophilus harrisii) and quolls (Dasyurus spp.), which are carnivorous marsupials, introduced foxes (Vulpes vulpes), feral cats, and raptors are predators of $R$. rattus (H. Stephens, pers. comm.). Skua (Stercorarius spp. [a predatory seabird]) are capable of consuming $R$. rattus, but there have not been any such reports for Pacific islands.

\section{RESPONSE TO MANAGEMENT}

Much interest in Pacific island rodent management occurred during the late 1800s and early 1900s as a result of expanding plantation agriculture and associated rodent damage. An additional period of increased interest in rodent research and management in the Pacific occurred during the 1940s-1950s, and it was associated with increased military operations in the Pacific and heightened incidences of rodent-borne diseases (Wilson 1968). Such interests initiated several multiyear research projects that focused on rat ecology and control in the Pacific; perhaps the most substantial ones were in Ponape (Pohnpei) from 1955 to 1958 (Storer 1962), Enewetak (Eniwetok) Atoll from 1964 to the late 1970s (Devaney et al. 1987), the Philippines from 1967 to 1983 (Fall and Sumangil 1980, Singleton and Petch 1984), Malaysia during the late 1970s (Dubock 1984, Richards and $\mathrm{Ku} 1987$ ), and Hawai'i from 1960 to the 1970s for bubonic plague monitoring research (Tomich et al. 1984) and 1966 to the present for ecology, crop damage evaluation, toxicant screening and registration, and conservation (Sugihara 2002, Pitt et al. 2011a).

The longest-standing and most common control measures that have been implemented are chemical control using rodenticides, physical control, and exclusion. Biological control has been unsuccessfully attempted several times with often unexpected and negative secondary effects. Often there are multiple control measures used simultaneously, woven into an integrated pest management strategy to control rodents (Witmer 2007). The management of rodents can be broadly separated into two distinct operational approaches: 
control and eradication. Rodent control (population and damage reduction) has historically been used to protect agricultural crops, human health, and natural resources. Control projects attempt to minimize the effects of rodents but require ongoing operations. Efforts to eradicate rodents from islands or fenced areas attempt to remove all rodents from an area over a short period and then maintain the area as rodent free using quarantine methods. Although eradicating rodents from small areas has been accomplished using ground-based trapping and persistent control methods, techniques developed over the last 20 yr to effectively aerially broadcast rodenticides have enabled much larger areas to be targeted (Howald et al. 2007). Since eradication programs began on small islands in the early 1960s, rats have been removed from over 300 islands around the world (Howald et al. 2007, Towns 2009, Witmer et al. 2011).

Gaining local community support for rat control or eradication, particularly when it involves the use of toxicants (rodenticides), is an important yet often difficult procedure. Ogden and Gilbert (2009) identified three reasons why gaining local support for rat eradications is typically challenging: (1) a lack of appreciation of the ecological damage resulting from rats, and therefore a low priority placed on their elimination, (2) suspicion by community members that conservationists want access to private lands and island-wide biosecurity, and 3) numerous regulatory barriers that delay decisions and actions and ultimately result in disinterest in such projects. Witmer et al. (2011) discussed many other challenges to invasive rodent eradication on islands.

\section{Chemical Control}

Rodenticides, such as those containing the anticoagulants diphacinone or brodifacoum, have been used on many Pacific islands to control $R$. rattus; one benefit over trapping is that rodenticide bait can simultaneously affect many rats over longer periods than a single baited trap. Rodenticide baiting is also generally less labor-intensive than trapping.
Witmer et al. (2007) reviewed the use of rodenticides for conservation efforts. Hawaiian sugarcane growers began using a myriad of mostly acute rodenticides (e.g., strychnine alkaloid, 1080) in the late 1800 s, but due to environmental health and human safety concerns these acute rodenticides were replaced in agricultural settings by first- and secondgeneration anticoagulant products like those containing warfarin or diphacinone (Sugihara 2002). Anticoagulants became the toxicants of choice for controlling rats beginning in the 1950s and were applied by placing the poison in plastic baggies and tossing them into agricultural fields and surrounding habitat (Lindsey et al. 1971). Threats to nontarget animals, including humans eating feral pigs (Sus scrofa) that were contaminated with rodenticides such as diphacinone, prompted the use of tamperproof bait stations (Tobin et al. 1990, Pitt et al. 2011c). Bait stations are used in agricultural, urban, and natural areas in contemporary Pacific islands to help control rodents. Bait degradation by fungi (especially in wet habitats) and consumption by ants, slugs, and other invertebrates reduces bait availability and palatability (Tobin et al. 1990, Mosher et al. 2010). In addition, prolonged use of a single type of rodenticide decreases its effectiveness (Doty 1945).

Pitt et al. (2011a) tested the efficacy and palatability of nine commercial rodenticide bait formulations; second-generation anticoagulants (e.g., brodifacoum) generally had the highest efficacy on $R$. rattus. Several types of toxicant baits require multiple feedings by each individual rat (e.g., diphacinone), whereas others are more toxic and typically require fewer feedings for a lethal dose (e.g., brodifacoum). Witmer et al. (2011) identified 40 islands or archipelagos in the United States where rodent (primarily Rattus spp.) eradication has been attempted, of which approximately half were Pacific islands, and almost all of them had used diphacinone; approximately $75 \%$ of these eradication attempts were successful. The larger islands where eradication has been attempted in the Pacific include Rat Island (2,900 ha) in Alaska where $R$. norvegicus was the target rodent species (Howald et al. 2007), and most recently Macquarie Island 
(128,860 ha) where $R$. rattus and M. musculus were the target rodents (Springer 2011).

Natural and artificial scents have been tested for their effectiveness in deterring $R$. rattus from particular food items. Synthetic scents were unsuccessful at deterring $R$. rattus from macadamia nut trees in Hawai'i (Burwash et al. 1998); yet mongoose urine and feces deterred $R$. rattus from traps in Hawai'i (Tobin et al. 1995). Capsaicin from chili fruits (Capsicum annuum) helped reduce Rattus spp. predation of bird eggs in New Zealand (Baylis et al. 2012). Price and Banks (2012) recently tested the effectiveness of pre-exposing $R$. rattus to scents of native species to potentially protect them before reintroducing such native species into areas with $R$. rattus. When $R$. rattus had encountered the prey odor (quail feces and feathers) before encountering the prey (quail eggs, which were used as surrogates to native bird eggs), there was a $62 \%$ reduction in quail egg predations relative to areas where the prey and odor were introduced simultaneously (Price and Banks 2012). It is unlikely that use of odors would be an effective long-term rat deterrent because individuals become accustomed to foreign scents and objects over time (Clapperton 2006).

Campaigns to sterilize wild rats were also attempted where the chemosterilant was administered in bait. Despite the successful sterilization of male rats in the laboratory, field trials failed as evidenced by many female rats impregnated in populations containing "sterile" males (Bowerman and Brooks 1971). Fumigating rat dens with poison gas has been attempted to reduce $R$. rattus populations, but it was also unsuccessful (Doty 1945).

Nelson et al. (2002) measured the costs and effectiveness of rat control (R. rattus and $R$. exulans) over 3 yr (January-April each year) using toxic bait and snap-traps in a remote Hawaiian montane rain forest. A 48 ha treatment area was monitored before, during, and after control. The cost was about US\$7000/ $\mathrm{km}^{2}(\$ 70 / \mathrm{ha})$ to reduce the rat population $58 \%-90 \%$ during $1 \mathrm{yr}$, yet the rat population rebounded from incursion from the perimeter each year such that rat numbers had returned to pretreatment levels by the beginning of the subsequent treatment. After the first year, the costs decreased to about $\$ 2000 / \mathrm{km}^{2}$ (\$20/ha). The authors' main conclusion from the study was that it is feasible to reduce rat abundance during a 4-month period each year during the forest bird breeding season (Nelson et al. 2002).

Howald et al. (2007) collated economic costs for 47 eradication campaigns that used toxicant bait; costs varied widely by island even when standardized by size (US $\$ 3000$ $\$ 20,000 /$ ha [adjusted to 2005 prices]) and bait delivery method (aerial broadcast, hand broadcast, bait station). Minimizing impacts of rodenticides to nontarget animals while ensuring that enough bait remains to expose all of the rats is important for successful rodent eradication programs (Witmer et al. 2007, Witmer et al. 2011).

\section{Physical Control}

Physical control methods (e.g., trapping, fencing) are frequently used to manage $R$. rattus because they do not require the use of toxicants. Both live- and kill-trapping techniques have been used to control $R$. rattus throughout the Pacific (see Sugihara et al. 1977). Continuous trapping campaigns almost certainly increases trap shyness, thereby affecting the degree to which rat populations are reduced and desired resources are protected (Tobin et al. 1990, Mosher et al. 2010). Many other factors may cause failure in rat control programs, and such factors may not always be obvious. For example, between 1914 and 1922, averages of 141,000 rats were removed annually using trapping methods from sugarcane plantations on Hawai'i Island, yet there was no apparent effect on the populations of the rats, and sugarcane continued to be damaged (Pemberton 1925).

Most trapping regimes place traps on the ground for ease of maintenance. However, in macadamia nut orchards in Hawai' $i$, Tobin et al. (1994) established snap-traps (41-49 traps/ha) in 8 to 11 ha blocks by attaching the traps to lower lateral branches in the trees. New Zealand and Hawai'i have both established large trapping grids in natural areas to control $R$. rattus and other rodents. In these large trapping grids, traps are checked, 
rebaited, and reset approximately every 2 weeks for several years or decades (King et al. 2011b, Pender et al. 2013). In Hawai'i, such large-scale (26 ha, 440 traps) snap-trapping grids have reduced $R$. rattus abundance and subsequently their fruit removal and seed predation of an endangered plant (Pender et al. 2013). However, Ogden and Gilbert (2009) found that trapping alone was not enough to reduce rat (primarily $R$. rattus) numbers for successful avian reintroductions on Great Barrier Island, New Zealand. After determining that ground-based rodent control was ineffective for improving nest success of the endangered cavity-nesting Kaua'i Thrush, puaiohi (Myadestes palmeri), Pitt et al. (2011b) developed a ratproof artificial nest box, using a design that was essentially a $36 \mathrm{~cm}$ length of $15 \mathrm{~cm}$ diameter plastic pipe with an entrance cut at an angle of 49 degrees. Multiple techniques are often needed to conserve and restore native species that are vulnerable to $R$. rattus.

Predatorproof fencing has been used in New Zealand for over a decade to wall-off problematic mammals (Scofield et al. 2011). More recently (within the last $3 \mathrm{yr}$ ), other $\mathrm{Pa}$ cific islands have begun to use predatorproof fencing to keep predators that are the size of M. musculus and larger out of natural and conservation areas. At Ka'ena Point Natural Area Reserve on $\mathrm{O}^{\prime} \mathrm{ahu}$, the number of breeding pairs of some seabirds, such as the Laysan $\mathrm{Al}$ batross (Phoebastria immutabilis), has apparently increased by $15 \%$, and Wedge-tailed Shearwater (Puffinus pacificus) chicks have tripled since the installation of the predatorproof fencing and the removal of introduced $R$. rattus, M. musculus, mongoose, cats, and dogs (Pala 2012). Often the individual impacts of $R$. rattus are unknown or cannot be easily determined because methods of control (e.g., trapping, toxicants, rodentproof fences) can apply to multiple invasive rodent species (e.g., mice, rats) and in many cases nonrodent species (e.g., mongoose, stoats). The costeffectiveness of predatorproof fencing in New Zealand is commonly debated, and Scofield et al. (2011) described the areas enclosed by predatorproof fencing as large zoos that do not allow population expansion and do not make economic sense over other methods of predator control. However, for animals that rely upon particular areas for annual reproduction (e.g., seabird nesting sites) or endangered animals that do not migrate great distances (e.g., tree snails), predatorproof fencing may be a particularly useful conservation technique.

\section{Biological Control}

Predators of $R$. rattus have been intentionally introduced to some Pacific islands in attempts to reduce the negative effects of rats. The small Indian mongoose is currently found in eight Pacific islands, including four in the $\mathrm{Ha}$ waiian Islands, two in Fiji, and two in Japan (Hays and Conant 2007). Although rodents were the dominant part of the mongoose diet in some Hawaiian sugarcane fields (Baldwin et al. 1952), rodents continued to thrive after mongoose introduction. In 1958, Hawai'i's Commissioners of Agriculture and Forestry approved the introduction of the Barn Owl to help control rodents (Tomich 1962), but this measure largely failed despite Barn Owls consuming many rats. Failed biocontrol attempts are worsened when the species introduced becomes problematic for native species or human health and safety (Pitt and Witmer 2007). For example, in contemporary Hawai' $i$, the Barn Owl and mongoose are predators of some native birds (Funasaki et al. 1988, Hays and Conant 2007; F. Duvall, pers. comm.). In addition, it is important to consider the eradication or control of introduced $R$. rattus from a multitrophic-level perspective (e.g., Zavaleta et al. 2001, Caut et al. 2009) because these rats are highly integrated into the food web (Figure 3 ) and consume both native and nonnative (in some cases highly invasive) organisms. In some situations, removal of rats can have negative repercussions by benefitting coexisting nonnative species (e.g., M. musculus, which is often a competitor with $R$. rattus), and these may include (1) extensive population growth, (2) equivalent or larger impacts than those of introduced $R$. rattus, and (3) greater difficulty of eradication relative to $R$. rattus (e.g., Courchamp et al. 1999, Zavaleta et al. 2001, Caut et al. 2007, Meyer and Shiels 2009). 
Dogs (Canis lupus familiaris) can be used to detect rats on islands. To prevent rodent reinvasion of islands, parts of New Zealand utilize specially trained rat dogs to find introduced Rattus spp. and M. musculus in conservation areas and on cargo transported between ports and islands (Towns 2009, Gsell et al. 2010). Additional rat control methods that have been historically attempted to reduce rat populations include destroying habitat around agricultural fields (Sugihara et al. 1977, Sugihara 2002) and introducing viral diseases (Doty 1945).

\section{PROGNOSIS}

When $R$. rattus arrived on most Pacific islands, there was probably at least one other nonnative rat species present (most likely $R$. exulans); therefore, the magnitude of ecosystem change resulting from $R$. rattus introduction may have been less than if no other rodents had been present. However, contemporary studies have indeed depicted $R$. rattus as the rodent species responsible for the most detrimental impacts on islands (Towns et al. 2006, Jones et al. 2008, Ruffino et al. 2009, Traveset et al. 2009). With a highly omnivorous diet (Figure 3), few organisms are safe from possible predation and/or indirect consequences of $R$. rattus invasion. There are many factors that may affect the future distribution of $R$. rattus, including changes in land uses, climate, and additional ecological factors such as the changes in densities, distributions, and dominance of other invasive rodents, particularly $M$. musculus and $R$. norvegicus. Rattus rattus will almost certainly continue to negatively affect the human food supply, spread disease, and alter native ecosystems.

Increased rat control and eradications across larger insular areas are expected in the future as tools and technology continue to improve. To ensure that such control and eradication campaigns are of value and will succeed, we first suggest that the conservation, human health, or economic goals are clear and feasible before initiation of the campaign. Local field research is necessary to identify species or ecosystem functions that suffer impacts from $R$. rattus. An understand- ing of the local food web will help reduce the chances of unexpected or negative consequences resulting from $R$. rattus removal (e.g., $M$. musculus population increases, which is often a more difficult species to eradicate than R. rattus [Harper and Cabrera 2010]), as well as help guide actions that will minimize both nontarget impacts and pollution from toxicants (Bowie and Ross 2006). Second, gaining social acceptance for the campaign is often an underestimated barrier to success; outreach and education early in the campaign as well as clear articulation of the goals and expected responses of the local species should therefore be disclosed (Moors et al. 1992, Ogden and Gilbert 2009). Finally, it is critical to secure posteradication funding and operational commitments for biosecurity and reinvasion response. To ensure success, posteradication monitoring and prevention of $R$. rattus reinvasions must occur indefinitely.

\section{ACKNOWLEDGMENTS}

We thank the following people for providing Rattus rattus body size data from islands throughout the Pacific: D. Balete, J. BaudatFanceschi, D. Buden, S. Caut, P. Dilks, R. Dowler, F. Duvall, L. Faulquier, R. Fewster, S. Gregory, A. Gupta, G. Harper, D. Harris, N. Holmes, K. Ishida, C.-C. Kuo, J. Lacoste, J. Lavers, L. Matisoo-Smith, G. McCormack, K. Nakata, M. Pascal, J. Penniman, R. Pierce, R. Powlesland, O. Robinet, J. Russell, A. Samaniego-Herrera, K. Springer, H. Stephens, D. Watling, A. Weiwel, A. Wegmann, and T. Yabe. We are also grateful for helpful comments by D. Clements, D. Drake, D. Duffy, M. Fall, and M. Tobin on early versions of the manuscript.

\section{Literature Cited}

Abe, T. 2007. Predator or disperser? A test of indigenous fruit preference of alien rats (Rattus rattus) on Nishi-jima (Ogasawara Islands). Pac. Conserv. Biol. 13:213-218.

Abe, T., and H. Umeno. 2011. Pattern of twig cutting by introduced rats in insular cloud forests. Pac. Sci. 65:27-39. 
Ahmad, N., V. R. Parshad, and C. S. Malhi. 1993. Deterioration of food in cold stores caused by Rattus rattus and its control: A case study. Int. Biodeterior. Biodegr. 32:305-312.

Alderton, D. 1996. Rodents of the world. Facts on File, New York.

Alley, J. C., P. H. Berben, J. S. Dugdale, B. M. Fitzgerald, P. I. Knightbridge, M. J. Meads, and R. A. Webster. 2001. Response of litter-dwelling arthropods on house mice to beech seeding in Orongorongo Valley, New Zealand. J. R. Soc. N. Z. 31:425-452.

Alterio, N., H. Moller, and K. Brown. 1999. Trappability and densities of stoats (Mustela erminea) and ship rats (Rattus rattus) in a South Island Nothofagus forest, New Zealand. N. Z. J. Ecol. 23:95-100.

Amarasekare, P. 1993. Potential impact of mammalian nest predators on endemic forest birds of western Mauna Kea, Hawaii. Conserv. Biol. 7:316-324.

1994. Ecology of introduced small mammals on western Mauna Kea, Hawaii. J. Mammal. 75:24-38.

Aplin, K. P., T. Chesser, and J. ten Have. 2003. Evolutionary biology of the genus Rattus: Profile of an archetypal rodent pest. Pages 487-498 in G. R. Singleton, L. A. Hinds, C. J. Krebs, and D. M. Spratt, eds. Rats, mice and people: Rodent biology and management. Australian Centre for International Agricultural Research, Canberra.

Atkinson, I. A. E. 1985. The spread of commensal species of Rattus to oceanic islands and their effects on avifaunas. Pages 35-81 in P. J. Moors, ed. Conservation of island birds. Int. Comm. Bird Preserv. Tech. Publ. No. 3.

1989. Introduced animals and extinction. Pages 54-75 in D. C. Western and M. C. Pearl, eds. Conservation for the twenty-first century. Oxford University Press, New York.

Atkinson, I. A. E., and D. R. Towns. 2005. Kiore. Pages 159-174 in C. M. King, ed. The handbook of New Zealand mammals. Oxford University Press, Melbourne.

Auld, T. D., I. Hutton, M. K. J. Ooi, and A. J. Denham. 2010. Disruption of recruitment in two endemic palms on Lord Howe Island by invasive rats. Biol. Invasions 12:3351-3361.

Baldwin, P. H., C. W. Schwartz, and E. R. Schwartz. 1952. Life history and economic status of the mongoose in Hawaii. J. Mammal. 33:335-356.

Banko, P. C., P. T. Oboyski, J. W. Slotterback, S. J. Dougill, D. M. Goltz, L. Johnson, M. E. Laut, and T. C. Murray. 2002. Availability of food resources, distribution of invasive species, and conservation of a Hawaiian bird along a gradient of elevation. J. Biogeogr. 29:789-808.

Banks, P. B., and N. K. Hughes. 2012. A review of the evidence for potential impacts of black rats (Rattus rattus) on wildlife and humans in Australia. Wildlife Res. 39:7888.

Barnett, S. A. 1963. The rat: A study in behaviour. Aldine Publishing Company, Chicago.

1964. Social stress. Pages 170-201 in

J. D. Carthy and C. L. Duddingtron, eds. Viewpoints in biology. Vol. 3. Plenum Publ. Corp., New York.

Baylis, S. M., P. Cassey, and M. E. Hauber. 2012. Capsaicin as a deterrent against introduced mammalian nest predators. Wilson J. Ornithol. 124:518-524.

Beaglehole, J. C., ed. 1969. The journals of Captain Cook on his voyages of discovery. Vol. II. The voyage of the Resolution and Adventure, 1772-1775. Hakluyt Society and Boyden Press, Woodbridge, United Kingdom.

Beard, K. H., and W. C. Pitt. 2006. Potential predators of an invasive frog (Eleutherodactylus coqui) in Hawaiian forests. J. Trop. Ecol. 22:345-347.

Bell, B. D. 1978. The Big South Cape islands rat irruption. Pages 33-40 in P. R. Dingwall, I. A. E. Atkinson, and C. Hay, eds. The ecology and control of rodents in New Zealand nature reserves. Department of Lands and Survey Information Series No. 4, Wellington.

Bentley, E. W., and E. J. Taylor. 1965. Growth of laboratory-reared ship rats (Rattus rattus L.). Ann. Appl. Biol. 55:193205. 
Blackwell, G. L., M. A. Potter, J. A. McLennan, and E. O. Minot. 2003. The role of predators in ship rat and house mouse eruptions: Drivers or passengers? Oikos 100:601-603.

Bowerman, A. M., and J. E. Brooks. 1971. Evaluation of U-5897 as a male chemosterilant for rat control. J. Wildl. Manage. 35:618-624.

Bowie, M. H., and J. G. Ross. 2006. Identification of weta foraging on brodifacoum bait and the risk of secondary poisoning for birds on Quail Island, Canterbury, New Zealand. N. Z. J. Ecol. 30:219-228.

Brown, K. P. 1997. Predation at nests of two New Zealand endemic passerines: Implications for bird community restoration. Pac. Conserv. Biol. 3:91-98.

Brown, K. P., H. Moller, J. Innes, and N. Alterio. 1996. Calibration of tunnel tracking rates to estimate relative abundance of ship rats (Rattus rattus) and mice (Mus musculus) in New Zealand forest. N. Z. J. Ecol. 20:271-275.

Burwash, M. D., M. E. Tobin, A. D. Woolhouse, and T. P. Sullivan. 1998. Field testing synthetic predator odors for roof rats (Rattus rattus) in Hawaiian macademia nut orchards. J. Chem. Ecol. 24:603-630.

Campbell, D. J. 1978. The effects of rats on vegetation. Pages 9-120 in P. R. Dingwall, I. A. E. Atkinson, and C. Hay, eds. The ecology and control of rodents in New Zealand nature reserves. Department of Lands and Survey Information Series No. 4, Wellington.

Campbell, D. J., H. Moller, G. W. Ramsay, and J. C. Watt. 1984. Observation on foods of kiore (Rattus exulans) found in husking stations on northern offshore islands of New Zealand. N. Z. J. Ecol. 7:131-138.

Carlton, J. T., and J. Hodder. 2003. Maritime mammals: Terrestrial mammals as consumers in marine intertidal communities. Mar. Ecol. Prog. Ser. 256:271-286.

Carvajal, A., and G. H. Adler. 2005. Biogeography of mammals on tropical Pacific islands. J. Biogeogr. 32:1561-1569.

Caut, S., E. Angulo, and F. Courchamp. $2008 a$. Dietary shifts of an invasive preda- tor: Rats, seabirds and turtles. J. Appl. Ecol. 45:428-437.

2008b. Discrimination factors $\left(\Delta^{15} \mathrm{~N}\right.$ and $\Delta^{13} \mathrm{C}$ ) in an omnivorous consumer: Effect of diet isotopic ratio. Funct. Ecol. 22:255-263.

2009. Avoiding surprise effects on Surprise Island: Alien species control in a multitrophic level perspective. Biol. Invasions 11:1689-1703.

Caut, S., J. G. Casanovas, E. Virgos, J. Lozano, G. W. Witmer, and F. Courchamp. 2007. Rats dying for mice: Modeling the competitor release effect. Austral Ecol. 32:858-868.

Chandrasekar-Rao, A., and M. E. Sunquist. 1996. Ecology of small mammals in tropical forest habitats of southern India. J. Trop. Ecol. 12:561-571.

Chiba, S. 2010a. Invasive rats alter assemblage characteristics of land snails in the Ogasawara Islands. Biol. Conserv. 143:1558-1563.

$2010 b$. Invasive non-native species' provision of refugia of an endangered native species. Conserv. Biol. 24:1141-1147.

Chimera, C. G., and D. R. Drake. 2011. Could poor dispersal contribute to predation by introduced rodents in Hawaiian dry forest? Biol. Invasions 13:1029-1042.

Clapperton, B. K. 2006. A review of the current knowledge of rodent behaviour in relation to control devices. Science and Technology Publishing, New Zealand Department of Conservation, Wellington.

Clark, D. A. 1980. Age- and sex-dependent foraging strategies of a small mammalian omnivore. J. Anim. Ecol. 49:549-563.

1981. Foraging patterns of black rats across a desert-montane forest gradient in the Galápagos Islands. Biotropica 13:182194.

1982. Foraging behavior of a vertebrate omnivore (Rattus rattus): Meal structure, sampling, and diet breadth. Ecology 63:763-772.

Clout, M. N. 1980. Ship rats (Rattus rattus L.) in a Pinus radiata plantation. N. Z. J. Ecol. 3:141-145.

Cole, F. R., L. L. Loope, A. C. Medeiros, C. E. Howe, and L. J. Anderson. 2000. Food 
habits of introduced rodents in highelevation shrubland of Haleakalā National Park, Maui, Hawai'i. Pac. Sci. 54:313-329.

Copson, G. R. 1986. The diet of introduced rodents Mus musculus L. and Rattus rattus L. on subantarctic Macquarie Island. Aust. Wildl. Res. 13:441-445.

Courchamp, F., M. Langlias, and G. Sugihara. 1999. Cats protecting birds: Modeling of the mesopredator release effect. J. Anim. Ecol. 68:282-292.

Cox, M. P. G., C. R. Dickman, and W. G. Cox. 2000. Use of habitat by the black rat (Rattus rattus) at North Head, New South Wales: An observational and experimental study. Austral Ecol. 25:375-385.

Cox, P. A. 1983. Extinction of the Hawaiian avifauna resulted in a change of pollinators for the ieie, Freycinetia arborea. Oikos 41:195-199.

Cruz, J. B., and F. Cruz. 1996. Conservation of the dark-rumped petrel Pterodroma phaeopygia of the Galápagos Islands, 1982-1991. Bird Conserv. Int. 6:23-32.

Curson, P., and K. W. McKracken. 1989. Plague in Sydney: The anatomy of an epidemic. University of New South Wales Press, Sydney.

Daniel, M. J. 1972. Bionomics of the ship rat (Rattus r. rattus) in a New Zealand indigenous forest. N. Z. J. Sci. 15:313-341.

- 1973. Seasonal diet of the ship rat (Rattus $r$. rattus) in lowland forest in New Zealand. Proc. N. Z. Ecol. Soc. 20:21-30. 1990. Greater short-tailed bat. Pages 131-136 in C. M. King, ed. The handbook of New Zealand mammals. Oxford University Press, Oxford.

Devaney, D. M., E. S. Reese, B. L. Burch, and P. Helfrich, eds. 1987. The natural history of Enewetak Atoll. U.S. Department of Energy, Washington, D.C.

Doty, R. E. 1945. Rat control on Hawaiian sugarcane plantations. Hawaii. Plant. Rec. 49:71-241.

Dowding, J. E., and E. C. Murphy. 1994. Ecology of ship rats (Rattus rattus) in a kauri (Agathis australis) forest of Northland, New Zealand. N.Z. J. Ecol. 18:19-27.

Drake, D. R., T. Bodey, J. Russell, D. Towns, M. Nogales, and L. Ruffino. 2011. Direct impacts of seabird predators on island biota other than seabirds. Pages 91-132 in C. P. H. Mulder, W. B. Anderson, D. R. Towns, and P. J. Bellingham, eds. Seabird islands: Ecology, invasion and restoration. Oxford University Press, Oxford.

Dubock, A. C., ed. 1984. Proceedings of a conference on The Organisation and Practice of Vertebrate Pest Control, 30 August-3 September 1982, Elvetham Hall, Hampshire, England. Imperial Chemical Industries, Haslemere.

Efford, M. G., B. M. Fitzgerald, B. J. Karl, and P. H. Berben. 2006. Population dynamics of ship rats Rattus rattus L. in Orongorongo Valley, New Zealand. N. Z. J. Zool. 33:273-297.

Elmouttie, D., and J. Wilson. 2005. The potential importance of nut removal by rodents from Australian macademia orchards. J. Environ. Manage. 77:79-83.

Erwin, T. L., and T. P. Young. 2010. A native besieged: Effects of nonnative frugivores and ground vegetation on fruit removal in a highly endangered Hawaiian shrub, Delissea rbytidosperma (Campanulaceae). Pac. Sci. 64:33-43.

Fall, M. W., A. B. Medina, and W. B. Jackson. 1971. Feeding patterns of Rattus rattus and Rattus exulans on Eniwetok Atoll, Marshall Islands. J. Mammal. 51:69-76.

Fall, M. W., and J. P. Sumangil. 1980. National rat control program in the Philippines. Pages 9-15 in Small mammals: Problems and control. BIOTROP Special Publication No. 12, Bogor, Indonesia.

Fisher, H. I., and P. H. Baldwin. 1946. War and the birds of Midway Atoll. Condor 48:3-15.

Fitzgerald, B. M., M. J. Daniel, A. E. Fitzgerald, B. J. Karl, M. J. Meads, and P. R. Notman. 1996. Factors contributing to fluctuations in house mice (Mus musculus) populations in hard beech (Nothofagus truncata) forest. J. R. Soc. N. Z. 26:237249.

Forget, P.-M., J. E. Lambert, P. E. Hulme, and S. B. Vander Wall, eds. 2005. Seed fate: Predation, dispersal and seedlings establishment. CAB International, Wallingford. 
Foster, S., C. King, B. Patty, and S. Miller. 2011. Tree-climbing capabilities of Norway and ship rats. N.Z.J.Zool. 38:285-296.

Fukami, T., D. A. Wardle, P. J. Bellingham, C. P. H. Mulder, D. R. Towns, G. W. Yeates, K. I. Bonner, M. S. Durrett, M. N. Grant-Hoffman, and W. M. Williamson. 2006. Above- and below-ground impacts of introduced predators in seabirddominated island ecosystems. Ecol. Lett. 9:1299-1307.

Funasaki, G. Y., P. Lai, L. M. Nakahara, J. W. Beardsley, and A. K. Ota. 1988. A review of biological control introductions in Hawaii: 1890-1985. Proc. Hawaii. Entomol. Soc. 28:105-160.

Gales, R. P. 1982. Age- and sex-related differences in diet selection by Rattus rattus on Stewart Island, New Zealand. N. Z. J. Zool. 9:463-466.

Golumbia, T. E. 2000. Introduced species management in Haida Gwaii (Queen Charlotte Islands). Pages 1-490 in L. M. Darling, ed. Proceedings of a conference on The Biology and Management of Species and Habitats at Risk, Kamloops, B.C. Vol. 1. British Columbia Ministry of Environment, Lands and Parks, Victoria, and University College of the Cariboo, Kamloops.

Grant-Hoffman, M. N., and P. S. Barboza. 2010. Herbivory in invasive rats: Criteria for food selection. Biol. Invasions 12:805825.

Grant-Hoffman, M. N., C. P. H. Mulder, and P. J. Bellingham. 2010. Effects of invasive rats and burrowing seabirds on seed and seedlings on New Zealand islands. Oecologia (Berl.) 162:1005-1016.

Gregory, S. D., and D. W. Macdonald. 2009. Prickly coexistence or blunt competition? Opuntia refugia in an invaded rodent community. Oecologia (Berl.) 159:225-236.

Gsell, A., J. Innes, P. de Monchy, and D. Brunton. 2010. The success of using trained dogs to locate sparse rodents in pest-free sanctuaries. Wildl. Res. 37:39-46.

Hadfield, M. G., S. E. Miller, and A. H. Carwile. 1993. The decimation of endemic Hawaiian tree snails by alien predators. Am. Zool. 33:610-622.
Hadfield, M. G., and J. E. Saufler. 2009. The demographics of destruction: Isolated populations of arboreal snails and sustained predation by rats on the island of Moloka' $i$ 1982-2006. Biol. Invasions 11:1595-1609.

Harper, G. A. 2006. Habitat use by three rat species (Rattus spp.) on an island without other mammalian predators. N. Z. J. Ecol. 30:321-333.

2007. Detecting predation of a burrow-nesting seabird by two introduced predators, using stable isotopes, dietary analysis and experimental removals. Wildi. Res. 34:443-453.

Harper, G. A., and L. F. Cabrera. 2010. Response of mice (Mus musculus) to the removal of black rats (Rattus rattus) in arid forest on Santa Cruz Island, Galápagos. Biol. Invasions 12:1449-1452.

Harris, D. B. 2009. Review of negative effects of introduced rodents on small mammals on islands. Biol. Invasions 11:1611-1630.

Harris, D. B., and D. W. Macdonald. 2007. Interference competition between introduced black rats and endemic Galapagos rice rats. Ecology 88:2330-2344.

Harrison, J. L. 1954. The natural food of some rats and other mammals. Bull. Raffles Mus. 25:157-165.

Hau, C. H. 1997. Tree seed predation on degraded hillsides in Hong Kong. For. Ecol. Manage. 99:215-221.

Hays, W. S. T., and S. Conant. 2007. Biology and impacts of Pacific island invasive species. 1. A worldwide review of effects of the small Indian mongoose, Herpestes javanicus (Carnivora: Herpestidae). Pac. Sci. 61:3-16.

Hood, G. A., R. D. Nass, G. D. Lindsey, and D. N. Hirata. 1971. Distribution and accumulation of rat damage in Hawaiian sugarcane. J. Wildl. Manage. 35:613-618.

Hooker, S., and J. Innes. 1995. Ranging behaviour of forest-dwelling ship rats, Rattus rattus, and effects of poisoning with brodifacoum. N. Z. J. Zool. 22:291-304.

Howald, G., C. J. Donlan, J. P. Galvan, J. C. Russell, J. Parkes, A. Samaniego, Y. Wang, D. Veitch, P. Genovesi, M. Pascal, A. Saunders, and B. Tershy. 2007. Invasive rodent eradication on islands. Conserv. Biol. 21:1258-1268. 
Igual, J. M., M. G. Forero, T. Gomez, J. F. Orueta, and D. Oro. 2006. Rat control and breeding performance in Cory's shearwater (Calonectris diomedea): Effects of poisoning effort and habitat features. Anim. Conserv. 9:59-65.

Innes, J. G. 2001. Advances in New Zealand mammalogy 1990-2000: European rats. J. R. Soc. N. Z. 31:111-125.

- 2005a. Ship rat. Pages 187-203 in C. A. King, ed. The handbook of New Zealand mammals. 2nd ed. Oxford University Press, Oxford. 2005b. Norway rat. Pages 174-187 in C. A. King, ed. The handbook of New Zealand mammals. 2nd ed. Oxford University Press, Oxford.

Innes, J. G., C. M. King, L. Bridgman, N. Fitzgerald, G. Arnold, and N. Cox. 2010. Effect of grazing on ship rat density in forest fragments of lowland Waikato, New Zealand. N. Z. J. Ecol. 34:227-232.

Innes, J. G., C. M. King, M. Flux, and M. O. Kimberley. 2001. Population biology of the ship rat and Norway rat in Pureora Forest Park, 1983-87. N. Z. J. Zool. 28:57-78.

Jackson, W. B., and M. L. Carpenter. 1966. Predatory behavior of rats at Eniwetok Atoll. Bull. Ecol. Soc. Am. 46:174.

Johnson, K. A., P. B. McQuillan, and J. B. Kirkpatrick. 2011. Nocturnal mammals, diurnal lizards, and the pollination ecology of the cryptic flowering Acrotriche serrulata (Ericaceae). Int. J. Plant Sci. 172:173-182.

Jones, H. P., B. R. Tershy, E. S. Zavaleta, D. A. Croll, B. S. Keitt, M. E. Finkelstein, and G. R. Howald. 2008. Severity of the effects of invasive rats on seabirds: A global review. Conserv. Biol. 22:16-26.

Jones, H. P., R. Williamhenry III, G. R. Howald, B. R. Tershy, and D. A. Croll. 2006. Predation of artificial Xantus's murrelet (Synthliboramphus bypoleucus scrippsi) nests before and after black rat (Rattus rattus) eradication. Environ. Conserv. 32:32325.

Kami, H. T. 1966. Foods of rodents in the Hamakua District, Hawaii. Pac. Sci. 20:367-373.

Kartman, L. 1954. Observations of Trypanosoma lewisi and Grabamella sp. in the blood of rats from the Hamakua District, island of Hawaii. J. Parasitol. 40:571-579.

Key, G. E., and R. D. Woods. 1996. Spooland-line studies on behavioural ecology of rats (Rattus spp.) in the Galápagos Islands. Can. J. Zool. 74:733-737.

King, C. M., S. Foster, and S. Miller. 2011a. Invasive European rats in Britain and New Zealand: Same species, different outcomes. J. Zool. 285:172-179.

King, C. M., J. G. Innes, D. Gleeson, N. Fitzgerald, T. Winstanley, B. O'Brien, L. Bridgman, and N. Cox. 2011b. Reinvasion by ship rats (Rattus rattus) of forest fragments after eradication. Biol Invasions 13:2391-2408.

Krebs, C. J., M. S. Gaines, B. L. Keller, J. H. Myer, and R. H. Tamarin. 1973. Population cycles in small rodents. Science (Washington, D.C.) 179:35-41.

Kuschel, G., and T. H. Worthy. 1996. Past distribution of large weevils (Coleoptera: Curculionidae) in the South Island, New Zealand, based on Holocene fossil remains. N. Z. Entomol. 19:15-22.

Lafferty, K. D., S. A. Hathaway, A. S. Wegmann, F. S. Shipley, A. R. Backlin, J. Helm, and R. N. Fisher. 2010. Stomach nematodes (Mastophorus muris) in rats (Rattus rattus) are associated with coconut (Cocos nucifera) habitat at Palmyra Atoll. J. Parasitol. 96:16-20.

Lapuz, R., H. Tani, K. Sasai, K. Shirota, H. Katoh, and E. Baba. 2008. The role of roof rats (Rattus rattus) in the spread of Salmonella Enteritidis and $S$. Infantis contamination in layer farms in eastern Japan. Epidemiol. Infect. 136:1235-1243.

Lindsey, G. D., S. M. Mosher, S. G. Fancy, and T. D. Smucker. 1999. Population structure and movement of introduced rats in an Hawaiian rainforest. Pac. Conserv. Biol. 5:94-102.

Lindsey, G. D., R. D. Nass, and G. A. Hood. 1971. An evaluation of bait stations for controlling rats in sugarcane. J. Wildl. Manage. 35:440-444.

Major, R. E. 1991. Identification of nest predators by photography, dummy eggs, and adhesive tape. Auk 108:190-196.

Major, R. E., and G. Gowing. 1994. An inexpensive photographic technique for identi- 
fying nest predators at active nests of birds. Wildl. Res. 21:657-666.

Mallick, S. A. 1992. Urine-marking in three species of Rattus. Wildl. Res. 19:89-93.

Marshall, J. T., Jr. 1955. Rats on Arno Atoll, Marshall Islands. J. Mammal. 36:259-263.

Martin, J.-L., J.-C. Thibault, and V. Bretagnolle. 2000. Black rats, island characteristics, and colonial nesting birds in the Mediterranean: Consequences of an ancient introduction. Conserv. Biol. 14:1452-1466.

McConkey, K. R., D. R. Drake, H. J. Meehan, and N. Parsons. 2003. Husking stations provide evidence of seed predation by introduced rodents in Tongan rain forests. Biol. Conserv. 109:221-225.

Meehan, A. P. 1984. Rats and mice, their biology and control. Rentokil Ltd., East Grinstead, United Kingdom.

Meerburg, B. G., G. R. Singleton, and A. Kijlstra. 2009. Rodent-borne diseases and their risks for public health. Crit. Rev. Microbiol. 35:221-270.

Meerburg, B. G., G. R. Singleton, and H. Leirs. 2008. The year of the rat ends: Time to fight hunger! Pest Manage. Sci. 65:351352.

Meyer, J.-Y., and J.-F. Butaud. 2009. The impacts of rats on the endangered native flora of French Polynesia (Pacific islands): Drivers of plant extinction or coup de grâce species? Biol.Invasions 11:1569-1585.

Meyer, W. M., III, and A. B. Shiels. 2009. Black rat (Rattus rattus) predation on nonindigenous snails in Hawai' $\mathrm{i}$ : Complex management implications. Pac. Sci. 63:339-347.

Miller, C. J., and T. K. Miller. 1995. Population dynamics and diet of rodents on Rangitoto Island, New Zealand, including the effects of a 1080 poison operation. N. Z. J. Ecol. 19:19-27.

Miller, R. W., A. M. Stuart, R. Joshi, P. B. Banks, and G. R. Singleton. 2008. Biology and management of rodent communities in complex agroecosystems: Rice terraces. Pages 25-36 in G. R. Singleton, R. Joshi, and L. S. Sebastian, eds. Philippine rats: Ecology and management. Philippines Rice Research Institute, Munoz.

Miller, S. D., J. C. Russell, H. E. MacInnes, J. Abdelkrim, and R. M. Fewster. 2010. Mul- tiple paternity in wild populations of invasive Rattus species. N. Z. J. Ecol. 34:360363.

Moles, A. T., and D. R. Drake. 1999. Postdispersal seed predation on eleven largeseeded species from the New Zealand flora: A preliminary study in secondary forest. N. Z. J. Bot. 37:679-685.

Moller, H., and J. L. Craig. 1987. The population ecology of Rattus exulans on Tiritiri Matangi Island, and a model of comparative population dynamics in New Zealand. N. Z. J. Zool. 14:305-328.

Moors, P. J., I. A. E. Atkinson, and G. H. Sherley. 1992. Reducing the rat threat to island birds. Bird Conserv. Int. 2:93-114.

Morriss, G. A., B. Warburton, M. L. Cross, and G. Nugent. 2012. Hoarding behavior by ship rats (Rattus rattus) in captivity and its relevance to the effectiveness of pest control. Eur. J. Wildl. Res. 58:483-488.

Mosher, S. M., D. Peters, L. Wilson, J. L. Rohrer, and A. Shiels. 2010. Control of the invasive black rat (Rattus rattus) and the $\mathrm{Pa}-$ cific rat (Rattus exulans) using a large scale trapping grid for endangered tree snail and plant conservation in Hawaii. Page 56 in D. Veitch, ed. Island invasives: Eradication and management. University of Auckland, New Zealand.

Mulder, C. P. H., W. B. Anderson, D. R. Towns, and P. J. Bellingham, eds. 2011. Seabird islands: Ecology, invasion and restoration. Oxford University Press, Oxford.

Mulder, C. P. H., M. N. Grant-Hoffman, D. R. Towns, P. J. Bellingham, D. A. Wardle, M. S. Durrett, T. Fukami, and K. I. Bonner. 2009. Direct and indirect effects of rats: Does rat eradication restore ecosystem functioning of New Zealand seabird islands? Biol. Invasions 11:1671-1688.

Musser, G. G., and M. D. Carleton. 2005. Family Muridae. Pages 894-1531 in D. E. Wilson and D. M. Reeder, eds. Mammal species of the world: A taxonomic and geographic reference. The John Hopkins University Press, Baltimore.

Nelson, J. T., B. L. Woodworth, S. G. Fancy, G. D. Linsey, and E. J. Tweed. 2002. Effectiveness of rodent control and monitoring techniques for a montane rainforest. Wildl. Soc. Bull. 30:82-92. 
Norman, F. I. 1970. Food preferences of an insular population of Rattus rattus. J. Zool. (Lond.) 162:493-503.

Norman, F. I., and R. V. Baudinette. 1969. Water economy and salt balance of an insular population of Rattus rattus Linnaeus. J. Mammal. 50:487-493.

Ogden, J., and J. Gilbert. 2009. Prospects for the eradication of rats from a large inhabited island: Community based ecosystem studies on Great Barrier Island, New Zealand. Biol. Invasions 111:1705-1717.

Pagès, M., Y. Chaval, V. Herbreteau, S. Waengsothorn, J.-F. Cosson, J.-P. Hugot, S. Morand, and J. Michaux. 2010. Revisiting the taxonomy of the Rattini tribe: A phylogeny-based delimitation of species boundaries. BMC Evol. Biol. 10:184.

Pala, C. 2012. Fences make good nest sites. Science (Washington, D.C.) 336:1628.

Peay, K. G., I. A. Dickie, D. A. Wardle, P. J. Bellingham, and T. Fukami. 2013. Rat invasion of islands alters fungal community structure, but not wood decomposition rates. Oikos 122:258-264.

Pemberton, C. E. 1925. The field rat in $\mathrm{Ha}-$ waii and its control. Hawaii. Sugar Plant. Assoc. Exp. Stn. Entomol. Ser. Bull. No. 17.

Pender, R. J., A. B. Shiels, L. Bialic-Murphy, and S. M. Mosher. 2013. Large-scale rodent control reduces pre- and postdispersal seed predation of the endangered Hawaiian lobeliad, Cyanea superba subsp. superba (Campanulaceae). Biol. Invasions 15:213-223.

Pérez, H. E., A. B. Shiels, H. M. Zaleski, and D. R. Drake. 2008. Germination after simulated rat damage in seeds of two endemic Hawaiian palm species. J. Trop. Ecol. 24:555-558.

Pimentel, D., R. Zuniga, and D. Morrison. 2005. Update on the environmental and economic costs associated with alieninvasive species in the United States. Ecol. Econ. 52:273-288.

Pitt, W. C., L. C. Driscoll, and R. T. Sugihara. 2011a. Efficacy of rodenticide baits for the control of three invasive rodent species in Hawaii. Arch. Environ. Contam. Toxicol. 60:533-542.
Pitt, W. C., L. C. Driscoll, and E. A. VanderWerf. 2011b. A rat-resistant artificial nest box for cavity nesting birds. Hum.-Wildl. Interact. 5:100-105.

Pitt, W. C., M. Higashi, and T. M. Primus. 2011c. The effect of cooking on diphacinone residues related to human consumption of feral pig tissue. Food Chem. Toxicol. 49:2030-2034.

Pitt, W. C., R. T. Sugihara, L. C. Driscoll, and D. S. Vice. 2011d. Physical and behavioural abilities of commensal rodents related to the design of selective rodenticide bait stations. Int. J. Pest Manage. 57:189_ 193.

Pitt, W. C., and G. W. Witmer. 2007. Invasive predators: A synthesis of the past, present, and future. Pages 265-293 in A. M. T. Elewa, ed. Predation in organisms: A distinct phenomenon. Springer Verlag, Heidelberg.

Price, C. J., and P. B. Banks. 2012. Exploiting olfactory learning in alien rats to protect birds' eggs. Proc. Natl. Acad. Sci. U.S.A. 109:19304-19309.

Prociv, P., D. M. Spratt, and M. S. Carlisle. 2000. Neuro-angiostrongyliasis: Unresolved issues. Int.J.Parasitol.30:1295-1303.

Pryde, M., P. Dilks, and I. Fraser. 2005. The home range of ship rats (Rattus rattus) in beech forest in the Eglington Valley, Fiordland, New Zealand: A pilot study. N. Z. J. Zool. 32:139-142.

Pye, T., R. Swaine, and R. D. Seppelt. 1999. Distribution and habitat use of the feral black rat (Rattus rattus) on subantarctic Macquarie Island. J. Zool. (Lond.) 247:429-438.

Ramsay, G. W. 1978. A review of the effects of rodents on the New Zealand invertebrate fauna. Pages 89-98 in P. R. Dingwall, I. A. E. Atkinson, and C. Hay, eds. The ecology and control of rodents in New Zealand nature reserves. Department of Lands and Survey Information Series No. 4, Wellington.

Richards, C. G. J., and T. K. Ku, eds. 1987. Control of mammal pests. Taylor and Francis, London.

Rickart, E. A., L. R. Heaney, P. D. Heideman, and R. C. B. Utzurrum. 1993. The 
distribution and ecology of mammals on Leyte, Biliran, and Maripipi Islands, Philippines. Fieldiana 72:1-62.

Robinet, O., J. L. Craig, and L. Chardonnet. 1998. Impact of rat species in Ouvea and Lifou (Loyalty Islands) and their consequences for conserving the endangered Ouvea Parakeet. Biol. Conserv. 86:223-232.

Robins, J. H., M. Hingston, E. MatisooSmith, and H. A. Ross. 2007. Identifying Rattus species using mitochondrial DNA. Mol. Ecol. Notes 7:717-729.

Ruffino, L., K. Bourgeois, E. Vidal, C. Duhem, M. Paracuellos, F. Escribano, P. Sposimo, N. Baccetti, M. Pascal, and D. Oro. 2009. Invasive rats and seabirds after 2,000 years of an unwanted coexistence on Mediterranean islands. Biol. Invasions 11:1631-1651.

Ruscoe, W. A., and E. C. Murphy. 2005. House mouse. Pages 204-222 in C. A. King, ed. The handbook of New Zealand mammals. 2nd ed. Oxford University Press, Oxford.

Ruscoe, W. A., D. S. L. Ramsey, R. P. Pech, P. J. Sweetapple, I. Yockney, M. C. Barron, M. Perry, G. Nugent, R. Carran, R. Warne, C. Brausch, and R. P. Duncan. 2011. Unexpected consequences of control: Competitive vs. predator release in a four-species assemblage of invasive mammals. Ecol. Lett. 14:1035-1042.

Russell, J. C., B. M. Beaven, J. W. B. MacKay, D. R. Towns, and M. N. Clout. 2008. Testing island biosecurity systems for invasive rats. Wildl. Res. 35:215-221.

Russell, J. C., and M. N. Clout. 2004. Modelling the distribution and interaction of introduced rodents on New Zealand offshore islands. Glob. Ecol. Biogeogr. 13:497-507.

Rutherford, M., G. Harper, and H. Moller. 2009. Denning behavior of ship rats (Rattus rattus) on Taukihepa, a seabird breeding island. N. Z. J. Zool. 36:343-353.

Samaniego-Herrera, A., A. Aguirre-Muñoz, M. Rodríguez-Malagón, R. GonzálezGómez, F. Torres-García, F. MéndezSánchez, M. Félix-Lizárraga, and $M$. Latofski-Robles. 2011. Rodent eradications on Mexican islands: Advances and challenges. Pages 350-355 in C. R. Veitch,
M. N. Clout, and D. R. Towns, eds. Island invasives: Eradication and management. IUCN, Gland, Switzerland.

Scofield, R. P., R. Cullen, and M. Wang. 2011. Are predator-proof fences the answer to New Zealand's terrestrial fauna biodiversity crisis? N. Z. J. Ecol. 35:312317.

Scowcroft, P. G., and H. F. Sakai. 1984. Stripping of Acacia koa bark by rats on Hawaii and Maui. Pac. Sci. 38:80-86.

Selvaraj, R., and G. Archunan. 2006. Efficacy of male scent glands and urine in masking poison bait odour in female house rats, Rattus rattus. J. Pest Manage. 79:255-258.

Seto, N. W. H., and S. Conant. 1996. The effects of rat (Rattus rattus) predation on the reproductive success of the Bonin Petrel (Pterodroma bypoleuca) on Midway Atoll. Colon. Waterbirds 19:171-185.

Shanker, K., and R. Sukumar. 1999. Synchrony in small mammal populations of montane forest patches in southern India. J. Anim. Ecol. 68:50-59.

Shaw, J. D., M. J. Hovenden, and D. M. Bergstrom. 2005. The impact of introduced ship rats (Rattus rattus) on seedling recruitment and distribution of a subantarctic megaherb (Pleurophyllum hookeri). Austral Ecol. 30:118-125.

Shiels, A. B. 2010. Ecology and impacts of introduced rodents (Rattus spp. and Mus musculus) in the Hawaiian Islands. Ph.D. diss., University of Hawai'i at Mānoa, Honolulu.

2011. Fruigivory by introduced black rats (Rattus rattus) promotes dispersal of invasive plant seeds. Biol. Invasions 13:781-792.

Shiels, A. B., and D. R. Drake. 2011. Are introduced rats (Rattus rattus) both seed predators and dispersers in Hawaii? Biol. Invasions 13:883-894.

Shiels, A. B., C. A. Flores, A. Khamsing, P. D. Krushelnycky, S. M. Mosher, and D. R. Drake. 2013. Dietary niche differentiation among three species of invasive rodents (Rattus rattus, R. exulans, Mus musculus). Biol. Invasions 15:1037-1048.

Singleton, G. R., and D. A. Petch. 1984. A review of the biology and management of 
rodent pests in Southeast Asia. ACIAR Technical Reports No. 30. Australian Centre for International Agicultural Research, Canberra.

Singleton, G. R., L. Smythe, G. Smith, D. M. Spratt, K. Aplin, and A. L. Smith. 2003. Rodent diseases in Southeast Asia and Australia: Inventory of recent surveys. Pages 25-30 in G. R. Singleton, L. A. Hinds, C. J. Krebs, and D. M. Spratt, eds. Rats, mice and people: Rodent biology and management. Australian Centre for International Agricultural Research, Canberra.

Springer, K. 2011. Planning processes for eradication of multiple pest species on Macquarie Island: An Australian case study. Pages 228-232 in C. N. Vietch, M. N. Clout, and D. R. Towns, eds. Island invasives: Eradication and management. IUCN, Gland, Switzerland.

St. Clair, J. J. H. 2011. The impacts of invasive rodents on island invertebrates. Biol. Conserv. 144:68-81.

Stewart, M. M., and L. L. Woolbright. 1996. Amphibians. Pages 273-320 in D. P. Reagan and R. B. Waide, eds. The food web of a tropical rain forest. University of Chicago Press, Chicago.

Stokes, V. L., P. B. Banks, R. P. Pech, and D. M. Spratt. 2009. Competition in an invaded rodent community reveals black rats as threats to native bush rats in littoral rainforest of south-eastern Australia. J. Appl. Ecol. 46:1239-1247.

2012. Influence of residency and social odors in interactions between competing native and alien rodents. Behav. Ecol. Sociobiol. 66:329-338.

Storer, T., ed. 1962. Pacific island rat ecology. Bernice P. Bishop Mus. Bull. 225.

Strecker, R. L., and W. B. Jackson. 1962. Habitats and habits. Pages 64-73 in T. Storer, ed. Pacific island rat ecology. Bernice P. Bishop Museum, Honolulu.

Sugihara, R. T. 1997. Abundance and diets of rats in two native Hawaiian forests. Pac. Sci. 51:189-198.

2002. Rodent damage research in $\mathrm{Ha}-$ waii: Changing times and priorities. Pages 40-45 in R. M. Timm and R. H. Schmidt, eds. Proceedings of the 20th Vertebrate
Pest Conference. University of California, Davis.

Sugihara, R. T., L. F. Pank, D. P. Fellows, D. N. Hirata, R. S. Stott, H. W. Hilton, and H. Kaya. 1977. Non-crop habitat manipulation as a means of controlling rats and reducing damage to sugarcane. Pages 83-90 in Hawaiian Sugar Technologists report. Hawaiian Sugar Planters Association, Honolulu.

Sweetapple, P. J., and G. Nugent. 2007. Ship rat demography and diet following possum control in a mixed podocarp-hardwood forest. N. Z. J. Ecol. 31:186-201.

Tamarin, R. H., and S. P. Malecha. 1971. The population biology of Hawaiian rodents: Demographic patterns. Ecology 52:383-394.

Tobin, M. E., R. M. Engeman, and R. T. Sugihara. 1995. Effects of mongoose odors on rat capture success. J. Chem. Ecol. 21:635-639.

Tobin, M. E., A. E. Koehler, and R. T. Sugihara. 1994. Seasonal patterns of fecundity and diet of roof rats in a Hawaiian macadamia orchard. Wildl. Res. 21:519-529.

Tobin, M. E., and R. T. Sugihara. 1992. Abundance and habitat relationship of rats in Hawaiian sugarcane fields. J. Wildl. Manage. 56:816-822.

Tobin, M. E., R. T. Sugihara, A. E. Koehler, and G. R. Ueunten. 1996. Seasonal activity and movements of Rattus rattus (Rodentia, Muridae) in a Hawaiian macadamia nut orchard. Mammalia 60:3-13.

Tobin, M. E., R. T. Sugihara, and A. K. Ota. 1990. Rodent damage to Hawaiian sugarcane. Pages 120-123 in L. R. Davis and R. E. Marsh, eds. Proceedings of the 14th Vertebrate Pest Conference, University of California, Davis.

Tomich, P. Q. 1962. Notes on the barn owl in Hawaii. 'Elepaio 23:16-17. 1986. Mammals in Hawai'i. 2nd ed. Bishop Museum Press, Honolulu.

Tomich, P. Q., A. M. Barnes, W. S. Devick, H. H. Higa, and G. E. Haas. 1984. Evidence for the extinction of the plague in Hawaii. Am. J. Epidemiol. 119:261-273.

Towns, D. R. 2009. Rodents. Pages 792-796 in R. G. Gillespie and D. A. Clague, eds. 
Encyclopedia of islands. University of California Press, Berkeley.

Towns, D. R., I. A. E. Atkinson, and C. H. Daugherty. 2006. Have the harmful effects of introduced rats on islands been exaggerated? Biol. Invasions 8:863-891.

Towns, D. R., D. A. Wardle, C. P. H. Mulder, G. W. Yeates, B. M. Fitzgerald, G. R. Parrish, P. J. Bellingham, and K. I. Bonner. 2009. Predation of seabirds by invasive rats: Multiple indirect consequences for invertebrate communities. Oikos 118:420430.

Traveset, A., M. Nogales, J. A. Alcover, J. D. Delgado, M. Lopez-Darias, D. Godoy, J. M. Igual, and P. Bover. 2009. A review of the effects of alien rodents in the Balearic (western Mediterranean Sea) and Canary Islands (eastern Atlantic Ocean). Biol. Invasions 11:1653-1670.

Twibell, J. 1973. The ecology of rodents in the Tonga Islands. Pac. Sci. 27:92-98.

Twigg, G. I. 1978. The role of rodents in plague dissemination: A worldwide review. Mammal Rev. 8:77-110.

Uowolo, A. L., and J. S. Denslow. 2008. Characteristics of the Psidium cattleianum (Myrtaceae) seed bank in Hawaiian lowland wet forest. Pac. Sci. 62:129-135.

VanderWerf, E. A. 2001. Rodent control decreases predation on artificial nests in O'ahu 'elepaio habitat. J. Field Ornithol. 72:448-457.

- 2012. Evolution of nesting height in an endangered Hawaiian forest bird in response to a non-native predator. Conserv. Biol. 26:905-911.

VanderWerf, E. A., and D. G. Smith. 2002. Effects of alien rodent control on demography of the O'ahu 'elepaio, an endangered Hawaiian forest bird. Pac. Conserv. Biol. 8:73-81.

Vernes, K., and L. Dunn. 2009. Mammal mycophagy and fungal spore dispersal across a steep environmental gradient in eastern Australia. Austral Ecol. 34:69-76.

Vernes, K., and K. McGrath. 2009. Are introduced black rats (Rattus rattus) a functional replacement for mycophagous native rodents in fragmented forests? Fungal Ecol. $2: 145-148$.
Waddell, A. H. 1969. Methyridine in treatment of experimental Capillaria bepatica infection in rat. Ann. Trop. Med. Parasitol. 63:63.

Wang, Q.-P., D.-H. Lai, X.-Q. Zhu, X.-G. Chen, and Z.-R. Lun. 2008. Human angiostrongyliasis. Lancet Infect. Dis. 8:621630.

Warham, J. 1990. The petrels: Their ecology and breeding systems. Academic Press, London.

Wardle, D. A., P. J. Bellingham, K. I. Bonner, and C. P. H. Mulder. 2009. Indirect effects of invasive predators on litter decomposition and nutrient resorption on seabirddominated islands. Ecology 90:452-464.

Wardle, D. A., P. J. Bellingham, T. Fukami, and C. P. H. Mulder. 2007. Promotion of ecosystem carbon sequestration by invasive predators. Biol. Lett. 3:479-482.

Watts, C. H. S., and H. J. Aslin. 1981. The rodents of Australia. Angus and Robertson, Sydney.

Wegmann, A. S. 2009. Limitations to tree seedling recruitment at Palmyra Atoll. Ph.D. diss., University of Hawai' $\mathrm{i}$ at Mānoa, Honolulu.

Weinbren, M. P., B. M. Weinbren, W. B. Jackson, and J. B. Villella. 1970. Studies on the roof rat (Rattus rattus) in the El Verde forest. Pages E169-E181 in H. T. Odum and R. F. Pigeon, eds. A tropical rain forest: A study of irradiation and ecology at El Verde, Puerto Rico. U.S. Atomic Energy Commission, Oak Ridge, Tennessee.

Whisson, D. A., J. H. Quinn, and K. C. Collins. 2007. Home range and movements of roof rat (Rattus rattus) in an old growth riparian forest, California. J. Mammal. 88:589-594.

Wiewel, A. S., A. A. Y. Adams, and G. H. Rodda. 2009. Distribution, density, and biomass of introduced small mammals in the southern Mariana Islands. Pac. Sci. 63:205-222.

Williams, P. A., B. J. Karl, P. Bannister, and W. G. Lee. 2000. Small mammals as potential seed dispersers in New Zealand. Austral Ecol. 25:523-532.

Wilson, D. J., M. G. Efford, S. J. Brown, J. F. Williamson, and G. J. McElrea. 2007. 
Estimating density of ship rats in New Zealand forests by capture-mark-recapture trapping. N. Z. J. Ecol. 31:47-59.

Wilson, E. J. 1968. The rat problem in the Pacific Basin. Pages 9-30 in Proceedings, Rodents as Factors in Disease and Economic Loss. Asia-Pacific Interchange, East-West Center, Honolulu, Hawai'i.

Witmer, G. 2007. The ecology of vertebrate pests and integrated pest management (IPM). Pages 393-410 in M. Kogan and P. Jepson, eds. Perspectives in ecological theory and integrated pest management. Cambridge University Press, Cambridge.

Witmer, G., J. D. Eisemann, and G. Howald. 2007. The use of rodenticides for conservation efforts. Pages 160-167 in D. L. Nolte, W. M. Arjo, and D. H. Stalman, eds. Proceedings of the 12th Wildlife Damage Management Conference. University of California, Davis.

Witmer, G. W., J. Pierce, and W. C. Pitt. 2011. Eradication of invasive rodents on islands of the United States. Pages 135-138 in C. N. Vietch, M. N. Clout, and D. R. Towns, eds. Island invasives: Eradication and management. IUCN, Gland, Switzerland.

Witmer, G., and G. Singleton. 2010. Sustained agriculture: The need to manage rodent damage. Pages 1-38 in F. C. Wager, ed. Agricultural production. Nova Science Publishers, New York.

Wong, M., A. R. Katz, D. Li, and B. A. Wilcox. 2012. Leptospira infection prevalence in small mammal host populations on three Hawaiian islands. Am. J. Trop. Med. Hyg. 87:337-341.

World Health Organization. 1995. International health regulations (1969). 3rd annotated ed. World Health Organization, Geneva.
Yabe, T. 1979. The relation of food habits to the ecological distributions of the Norway rat (Rattus norvegicus) and the roof rat $(R$. rattus). Jpn. J. Ecol. 29:235-244.

Yabe, T., T. Hashimoto, M. Takiguchi, M. Aoki, and M. Fujita. 2010. Twig cutting by the black rat, Rattus rattus (Rodentia: Muridae), on the Ogasawara (Bonin) Islands. Pac. Sci. 64:93-97.

Yabe, T., T. Hashimoto, M. Takiguchi, M. Aoki, and K. Kawakami. 2009. Seabirds in the stomach contents of black rats Rattus rattus on Higashijima, the Ogasawara (Bonin) Islands, Japan. Mar. Ornithol. 37:293-295.

Yamashita, N., N. Tanaka, Y. Hoshi, H. Kushima, and K. Kamo. 2003. Seed and seedling demography of invasive and native trees of subtropical Pacific islands. J. Veg. Sci. 14:15-24.

Yom-Tov, Y., S. Yom-Tov, and H. Moller. 1999. Competition, coexistence, and adaptation amongst rodent invaders to Pacific and New Zealand islands. J. Biogeogr. 26:947-958.

Yoshida, T. H., H. Kato, K. Tsuchiya, T. Sagai, and K. Moriwaki. 1974. Cytogenetical survey of black rats, Rattus rattus, in Southwest and central Asia, with special regard to the evolutional relationship between three geographical types. Chromosoma 45:99-109.

Zarzoso-Lacoste, D., L. Ruffino, and E. Vidal. 2011. Limited predatory capacity of introduced black rats on bird eggs: An experimental approach. J. Zool. (Lond.) 285:188-193.

Zavaleta, E. S., R. J. Hobbs, and H. A. Mooney. 2001. Viewing invasive species removal in a whole-ecosystem context. Trends Ecol. Evol. 16:454-459. 